\title{
Consequences of removal of exotic species (eucalyptus) on carbon and nitrogen cycles in the soil-plant system in a secondary tropical Atlantic forest in Brazil with a dual-isotope approach
}

\author{
Milena C Teixeira ${ }^{1}$, Angela P Vitoria ${ }^{\text {Corresp., }}{ }^{1}$, Carlos E Rezende ${ }^{1}$, Marcelo G Almeida ${ }^{1}$, Gabriela B Nardoto ${ }^{\text {Corresp. } 2}$ \\ 1 Laboratório de Ciências Ambientais, Universidade Estadual do Norte Fluminense Darcy Ribeiro, Campos dos Goytacazes, Rio de Janeiro, Brazil \\ 2 Departamento de Ecologia, Universidade de Brasília, Brasília, Distrito Federal, Brazil \\ Corresponding Authors: Angela P Vitoria, Gabriela B Nardoto \\ Email address: apvitoria@uenf.br, gbnardoto@unb.br
}

The impact of exotic species on heterogeneous native tropical forest requires the understanding on which temporal and spatial scales these processes take place.

Functional tracers such as carbon $\left(\delta^{13} \mathrm{C}\right)$ and nitrogen $\left(\delta^{15} \mathrm{~N}\right)$ isotopic composition in the soil-plant system might help track the alterations induced by the exotic species. Thus, we assess the effects from the removal of the exotic species eucalyptus (Corymbia cytriodora) in an Atlantic forest Reserve, and eucalyptus removal on the alteration of the nutrient dynamics (carbon and nitrogen). The hypotheses were: (1) the eucalyptus permanence time altered $\delta^{13}$ Cand $\delta^{15} \mathrm{~N}$ in leaves, soils and litter fractions (leaves, wood, flowers +fruits, and rest); and (2) eucalyptus removal furthered decomposition process of the soil organic matter. Hence, we determined the soil granulometry, the $\delta^{13} \mathrm{Cand} \delta^{15} \mathrm{Nin}$ leaves, in the superficial soil layer, and litter in three sites: a secondary forest in the Atlantic forest, and other two sites where eucalyptus had been removed in different times: 12 and 3 months ago (M12 and M3, respectively). Litter samples presented intermediate $\delta^{13}$ Cand $\delta^{15} \mathrm{~N}$ values in comparison with leaves and soil. In the $M 3$, the greater $\delta^{13} \mathrm{Cvalues}$ in both litter rest fraction and soil indicate the presence, cycling and soil incorporation of $\mathrm{C}$, coming from the $\mathrm{C}_{4}$ photosynthesis of grassy species (Poaceae). In the secondary forest, the soil

$\delta^{15} \mathrm{~N}$ values were twice higher, compared with the eucalyptus removal sites, revealing the negative influence from these exotic species upon the ecosystem N dynamics. In the M12, the leaves presented higher $\delta^{13} \mathrm{C}$ mean value and lower $\delta^{15} \mathrm{~N}$ values, compared with those from the other sites. The difference of $\delta^{13} \mathrm{C}$ values in the litter fractions regarding the soil led to a greater fractioning of ${ }^{13} \mathrm{C}$ in all sites, except the flower+fruit fractions in the 
secondary forest, and the rest fraction in the M3 site. We conclude that the permanence of this exotic species and the eucalyptus removal have altered the $\mathrm{C}$ and $\mathrm{N}$ isotopic and elemental compositions in the soil-plant system. Our results suggest there was organic matter decomposition in all litter fractions and in all sites. However, a greater organic matter decomposition process was observed in the M3 soil, possibly because of a more intense recent input of vegetal material, as well as the presence of grassy, easilydecomposing herbaceous species, only in this site. Therefore, the dual-isotope approach generated a more integrated picture of the impact on the ecosystem after removing eucalyptus in this secondary Atlantic forest, and could be regarded as an option for future eucalyptus removal studies. 


\section{Consequences of removal of exotic species (eucalyptus) on}

2 carbon and nitrogen cycles in the soil-plant system in a

3 secondary tropical Atlantic forest in Brazil with a dual-

4 isotope approach.

Milena Carvalho Teixeira ${ }^{1}$, Angela Pierre Vitoria ${ }^{1}$, Carlos Eduardo de Rezende ${ }^{1}$, Marcelo Gomes

7 de Almeida ${ }^{1}$, and Gabriela Bielefeld Nardoto ${ }^{2}$

8

${ }^{1}$ Laboratório de Ciências Ambientais, Universidade Estadual do Norte Fluminense Darcy Ribeiro, Campos dos Goytacazes, Rio de Janeiro, Brazil

Corresponding Authors:

Gabriela Bielefeld Nardoto

Email address: gbnardoto@gmail.com

Angela Pierre Vitoria

Email address: apvitoria@gmail.com

\section{Abstract}

The impact of exotic species on heterogeneous native tropical forests requires the understanding of which temporal and spatial scales these processes take place. Functional tracers such as carbon $\left(\delta^{13} \mathrm{C}\right)$ and nitrogen $\left(\delta^{15} \mathrm{~N}\right)$ isotopic composition in the soil-plant system might help track the alterations induced by the exotic species. Thus, we assess the effects of the removal of the exotic species eucalyptus (Corymbia cytriodora) in an Atlantic forest Reserve and eucalyptus removal on the alteration of the nutrient dynamics (carbon and nitrogen). The hypotheses were: (1) the eucalyptus permanence time altered $\delta^{13} \mathrm{C}$ and $\delta^{15} \mathrm{~N}$ in leaves, soils and litter fractions (leaves, wood, flowers+fruits, and rest); and (2) eucalyptus removal furthered decomposition process of the soil organic matter. Hence, we determined the soil granulometry, the $\delta^{13} \mathrm{C}$ and $\delta^{15} \mathrm{~N}$ in leaves, in the superficial soil layer, and litter in three sites: a secondary forest in the Atlantic forest, and other two sites where eucalyptus had been removed in different times: 12 and 3 months ago (M12 and M3, respectively). Litter samples presented intermediate $\delta^{13} \mathrm{C}$ and $\delta^{15} \mathrm{~N}$ values in comparison with leaves and soil. In the M3 site, the higher $\delta^{13} \mathrm{C}$ values in both litter rest fraction and soil indicate the presence, and carbon soil incorporation coming from the $\mathrm{C}_{4}$ photosynthesis of grassy species (Poaceae). In the secondary forest, the soil $\delta^{15} \mathrm{~N}$ values were twice higher, compared with the eucalyptus removal sites, revealing the negative influence from these exotic species upon the ecosystem $\mathrm{N}$ dynamics. In the M12 site, the leaves presented 
difference of $\delta^{13} \mathrm{C}$ values in the litter fractions regarding the soil led to an increase of soil $\delta^{13} \mathrm{C}$ in all sites. We conclude that the permanence of this exotic species and the eucalyptus removal have altered the $\mathrm{C}$ and $\mathrm{N}$ isotopic and elemental compositions in the soil-plant system. However, a greater organic matter decomposition process was observed in the M3 site soil, possibly because of a more intense recent input of vegetal material, as well as the presence of grassy, easily-decomposition herbaceous species, only in this site. Therefore, the dual-isotope approach generated a more integrated picture of the impact on the ecosystem after removing eucalyptus in this secondary Atlantic forest and could be an option to be used for future eucalyptus removal studies.

Subjects Biodiversity, Conservation Biology, Ecology, Plant Science

Keywords Superficial soil layer, Eucalyptus removal, Litter, Nutrient cycles, Soil organic matter, Stable isotopes

\section{INTRODUCTION}

Tropical forests have been reduced to fragments of their original extensions on account of activities such as urbanization, agriculture, and the replacement of native vegetation by exotic tree species for commercial purposes, as eucalyptus and pine (Morellato \& Haddad, 2000; Baptista \& Rudel, 2006; Wright \& Muller-Landau, 2006; Brockerhoff et al., 2008; Vitória et al., 2019). Historically in Brazil, the eucalyptus plantation has been associated with the suppression of native species, mainly in the Atlantic forest southeast region (Brockerhoff et al., 2008). In biome restoration-aimed efforts, this fast-growing exotic species has been used as a renewable alternative in order to connect fragments from the installation of ecological corridors, or the mixed plantation together with native species (Brockerhoff et al., 2008). However, the presence of eucalyptus close or consorted to secondary forests changes the natural dynamics of these forests, since this species offers fewer resources for the pollinating and dispersing fauna and which may interfere in both C and N cycles (Guo \& Sims, 1999; Dutta \& Agrawal, 2001). The eucalyptus litter decomposes slowly, has low nutritional attributes, and presents a higher $\mathrm{C} / \mathrm{N}$ ratio in comparison to the majority of other native species from tropical forests (Rezende et al., 2001; Villela et al., 2001; Gama-Rodrigues et al., 2008).

In the sites destined exclusively to biodiversity protection, the eucalyptus has been suppressed from vegetation via removal, mixed plantations, and deforestation, which may cause variations in $\mathrm{C}$ and $\mathrm{N}$ cycles within the forest ecosystem compartments (Costa et al., 2005; GamaRodrigues et al., 2005). The $\mathrm{N}$ soil supplies are controlled, specially, over the climate conditions and by the vegetation (Vitousek \& Madson, 1984). The forests stock C, which is accumulated between the photosynthesis and breathing balance in this ecosystem (Pregitzer \& Euskirchen, 2004). Nonetheless, the $\mathrm{C}$ cycle and supply throughout the forest depend on its own age, from the period of natural or anthropic disturbances, and from practices of landscape usage such as deforestation and degradation (Houghton, 2005). Hence, the vegetation removal and/or 
78 replacement is likely to transform a C-storage ecosystem into a C-source one to the atmosphere 79 (Bayer et al., 2004; Diekow et al., 2005).

80 The $\mathrm{C}$ and $\mathrm{N}$ cycles are fundamental ecological processes in the soil-plant system dynamics, 81 thus influencing growth strategies, the subsistence of vegetal species, and the efficient 82 applications of these elements by the community (Vitousek \& Sanford, 1986). Within this 83 system, the litter works as a reservoir for these and other elements. The soil organic matter 84 decomposition rate and, consequently, the $\mathrm{C}$ and $\mathrm{N}$ release to the soil are related to biotic factors, 85 namely the soil microbial activity, $\mathrm{N}$ concentration in plants, the chemical composition of the 86 litter material, as well as abiotic variables, as the soil humidity, temperature, texture and depth 87 (Stemmer et al., 1998; Bustamante et al., 2004; Martinelli et al., 2009; Trumbore \& Camargo, 88 2009). The soil texture influences the dynamics of $\mathrm{C}$ and $\mathrm{N}$, whence more clayey and humid soils 89 present higher retention capacity of organic matter (Stemmer et al., 1998; Telles et al., 2003; 90 Gama-Rodrigues et al., 2005). In more sandy soils, with low retention capacity of organic 91 matter, few differences are observed between $\mathrm{C}$ and $\mathrm{N}$ values in the soil and those of the organic 92 93 94 95 96 97 98 matter depicts the combination of past and current vegetations (Freitas et al., 2001; Mardegan et al., 2009). In the leaves, the stomas control $\mathrm{CO}_{2}$ entry into the substomatal cavity, which has a direct impact on $\delta^{13} \mathrm{C}$ present in vegetal tissues. At first, any factor that alters the atmospheric $\mathrm{CO}_{2}$ isotopic ratio and/or the $\mathrm{c}_{\mathrm{i}} / \mathrm{c}_{\mathrm{a}}$ (internal C/atmospheric C) relationship, will then modify $\delta^{13} \mathrm{C}$ (Farquhar et al., 1982; Mardegan et al., 2009; Vitória et al., 2016; Teixeira et al., 2018; Vitória et al., 2018). Hence, in the leaves, the $\delta^{13} \mathrm{C}$ is determined by processes which interfere and modulate photosynthesis, for example the photosynthetic syndrome, the environmental conditions (for instance irradiance, temperature, humidity), and the availability of water and nutrients (Farquhar et al., 1989; Teixeira et al., 2015; Vitória et al., 2016; Teixeira et al., 2018; Vitória et al., 2018; Vitória et al., 2019).

Several biogeochemical processes contribute toward the $\mathrm{N}$ isotopic composition $\left(\delta^{15} \mathrm{~N}\right)$ in leaves, that include nitrification, mineralization, lixiviation, denitrification, volatilization, abiotic factors (temperature and humidity), bacterial colonization, time and space variations in terms of $\mathrm{N}$ availability in the soil, the type of $\mathrm{N}$ source (organic or inorganic), soil texture, among others (Dawson et al., 2002; Ometto et al., 2006; Vallano \& Sparks, 2013). Tropical forests are dynamic environments for the $\mathrm{N}$-cycle-related processes, thus resulting in $\mathrm{N}$ fractionation and enrichment of ${ }^{15} \mathrm{~N}$ in the soil-plant system (Martinelli et al., 1999; Nardoto et al., 2008; Craine et al., 2009; Vitória et al., 2018). (Martinelli et al., 1999; Nardoto et al., 2008; Craine et al., 2009; Vitória et al., 2018). Leaf $\mathrm{C} / \mathrm{N}$ ratio and soil $\mathrm{N}$ mineralization rates influence soil organic matter dynamics and consequently, the $\delta^{15} \mathrm{~N}$ in leaves (Craine et al., 2009). Soil $\mathrm{N}$ transformation rates and $\mathrm{N}$ losses to the atmosphere will, ultimately, regulate $\mathrm{N}$ availability in an ecosystem and consequently, the $\delta^{15} \mathrm{~N}$ in the soil-plant system (Craine et al., 2009). Since $\mathrm{N}$ availability is higher in tropical forests than in temperate forests (Vitousek \& Sanford, 1986; Martinelli et al., 1999; Boeger et al., 2005), these tropical forests will have, as a consequence, higher $\delta^{15} \mathrm{~N}$ in the soil-plant system compared to the temperate forests under lower $\mathrm{N}$ availability 
118 (Craine et al., 2009). The high amount of precipitation and almost no seasonality in temperature

119

120

121

122

123

124

125

126

127

128

129

130

131

132

133

134

135

136

137

138

139

140

141

142

143

144

145

146

147

148

149

150

151

152

153

154

155

156

and humidity in those tropical forests tend to provide favorable conditions to decomposition activity by soil organisms, and consequently high decomposition rates most of the year (Vitousek \& Matson, 1984; Davidson et al., 2007; Nardoto et al., 2008; Viani, 2010; Gragnani, 2014). Therefore, both litter decomposition and nutrient mineralization promote nutrient availability in soil, mainly $\mathrm{N}$ and $\mathrm{P}$, thus triggering variations in $\delta^{15} \mathrm{~N}$ (Dawson et al., 2002; Bustamante et al., 2004; Ometto et al., 2006). Tropical and humid rainforests have higher concentrations of $\mathrm{C}$ and $\mathrm{N}$ in the soil during rainy season (Mazurec et al., 2003; Gama-Rodrigues et al., 2008;). The decomposition acceleration in rainy season is attributed to an increment in decomposers and macro-fauna, and, in some forests, to a more significant growth of fine roots, caused by the availability of water and nutrients (Stemmer et al., 1998; Bustamante et al., 2004; Martinelli et al., 2009).

In the União Biological Reserve (Rebio União), a fragment of the Atlantic forest with integral nature protection located in southwest Brazil presents specific forestry management which consists on the removal of eucalyptus trees (Corymbia citriodora) until 2015 aiming to restore the native flora. With management, the irradiance patterns, humidity, and site temperature were altered, as well as the $\delta^{13} \mathrm{C}$ from the main regenerating species from the understory (Teixeira et al., 2015; Vitoria etal., 2016; Teixeira et al., 2018). Other ecological processes might as well have been affected by management, like the $\mathrm{C}$ and $\mathrm{N}$ dynamics in the soil-plant system.

The objective of this work was to study the forestry management effect of eucalyptus removal in the Rebio União by determining $\delta^{13} \mathrm{C}$ and $\delta^{15} \mathrm{~N}$ in the soil-plant system, as well as the soil granulometry in three sites: a secondary forest in the Atlantic forest, and two other sites where eucalyptus had been removed at different times: 12 months and 3 months before sampling(M12 and M3, respectively). These study hypotheses were: (1) the eucalyptus permanence time altered the $\delta^{13} \mathrm{C}$ and $\delta^{15} \mathrm{~N}$ in leaves, soil, and organic litter fractions (leaves, wood, flowers + fruits and rest) and; (2) eucalyptus removal furthered decomposition process of the soil organic matter.

\section{Materials \& Methods}

\section{Site of study, species and sampling period}

This study was held in the União Biological Reserve (Rebio União), in Rio de Janeiro State, Brazil ( $\left.22^{\circ} 27^{\prime} \mathrm{S} ; 42^{\circ} 02^{\prime} \mathrm{W}\right)$. Field experiments were approved by SISBIO/ICMBio/MMA, to develop the project "Capacidade aclimatativa de espécies da Mata Atlântica após manejo de eucalipto na Reserva Biológica da União" at the Rebio União, Rio de Janeiro, Brazil, under the licence number 37996-3.

The climate in the region is humid tropical $A w$ (Alvares et al., 2013), with a yearly average temperature of $25^{\circ} \mathrm{C}$ and an annual rainfall of $1920 \mathrm{~mm}(85 \%$ being between October and April). This Reserve comprises around 7800 ha of ombrophilous dense Atlantic forest, of which around 220 ha had the native tree vegetation suppressed and replaced by eucalyptus crops (Corymbia citriodora) (Hook.) K.D. Hill \& L.A.S. Johnson). The eucalyptus tree plantations ceased to 
157

158

159

160

161

162

163

164

165

166

167

168

169

170

171

172

173

174

175

176

177

178

179

180

181

182

183

184

185

186

187

188

189

190

191

192

193

194

195

196

receive silvicultural treatments related to understory removal in 1996. The eucalyptus was clearcut between 2009 and 2015.

We realized this research in three latosolic dystrophic red-yellow argisoil sites, classified according to Embrapa (1999); Miranda et al. (2007) and dos Santos et al. (2018). One site is a well-preserved secondary forest; whereas the other two are eucalyptus-harvested sites, employing clear-cutting, with a single difference related to after-handling time: the M12 (where eucalyptus had been removed 12 months before our evaluation); and the M3 (where eucalyptus removal had happened three months before assessment) (Fig. 1, Table 1, DataS1). The post eucalyptus removal times were chosen according to the management activities in the Rebio União, and is sufficient to detect processes related to the decomposition of organic matter. For each of these sites, three ecosystem compartments were studied: photosynthetically active leaves, organic litter fractions, and the soil, due to its relation with organic matter decomposition processes.

For the elemental and isotopic analyses of $\mathrm{C}$ and $\mathrm{N}$, we considered the most abundant tree species within the eucalyptus removal sites M12 and M3 (Evaristo et al., 2011), being all of those from the initial succession stratum (Lorenzi, 2000): Siparuna guianensis Aubl.

(Siparunaceae), Xylopia sericea A. St.-Hill (Annonaceae), and Byrsonima sericea D.C. (Malpighiaceae). We collected the leaves from the eucalyptus removal sites with individuals from 2 to 5 meters high, and diameter at breast height $(\mathrm{DBH})>5 \mathrm{~cm}$. For a better diversity-related sampling within the secondary forest site, we collected samples from 20 species (DataS2) according to their importance value index (IVI), all of those ranging between 10 to 15 meters tall, and with a DBH $>10 \mathrm{~cm}$. The leaves, plant litter, and soils were collected in December 2013 during the rainy season.

\section{Determination of the elemental and isotopic composition of $\mathrm{C}$ and $\mathrm{N}$ within the leaves, litter and soil compartments and sample number}

We standardized collected samples of the third sun-exposed photosynthetically active pair of leaves, once photosynthetic activity and irradiance variation are important factors to determine $\delta^{13} \mathrm{C}$ (Vitória et al., 2016). Young leaves are not photosynthetically active and enriched in ${ }^{13} \mathrm{C}$ (Cernusak et al., 2009), similar to shadow leaves (Vitória et al., 2016). Besides, great variation can be found in $\delta^{13} \mathrm{C}$ within a single tree crown on account of the variations in environmental conditions (Le Roux et al., 2001; McDowell et al., 2011). Thus, sun-exposed branches of individuals of the secondary forest were collected from the canopy by using high pruning shears. Sun-leaves from eucalyptus removal areas (M3 and M12 sites) were manually collected. For each species, 5 to 7 leaves per individual were sampled and then dried in an oven at $50{ }^{\circ} \mathrm{C}$ for 48 $\mathrm{h}$ (Vitória et al., 2016). Afterward the leaves were macerated in liquid $\mathrm{N}$ and homogenized per individual. Regarding the eucalyptus removal sites, the samples collected comprise 5 to 15 individuals $(n=5-15)$ of the three species from the regenerating understory in both the M12 and the M3 sites. For a better diversity-related sampling within the secondary forest site, we collected samples from 20 species (DataS2). For all of these 20 species, 5 adult individuals had their 
197 leaves sampled, except for the following species: Ficus gomelleira $(\mathrm{n}=4)$, Cupania racemosa $(\mathrm{n}$

198

199

200

201

202

203

204

205

206

207

208

209

210

211

212

213

214

215

216

217

218

219

220

221

222

223

224

225

226

227

228

229

230

231

232

233

234

235

$=4)$, Brosimum glazioui $(\mathrm{n}=4)$, Virola gardneri $(\mathrm{n}=2)$, Micropholis guianensis $(\mathrm{n}=2)$, Ocotea diospyrifolia $(\mathrm{n}=2)$. Thus, for the secondary forest, we collected samples from 2 to 5 individuals $(\mathrm{n}=2-5)$.

The litter layer on the soil was collected via a 20 x $20 \mathrm{~cm}$ metal frame randomly arranged 25 times in each of the three study sites, totaling 75 samples with $400 \mathrm{~cm}^{2}$ of litter. The collect points were chosen at random. The collected material was dried at constant weight in an oven at $50{ }^{\circ} \mathrm{C}$ for $48 \mathrm{~h}$ (Mayor et al., 2014, Camara et al., 2018). These samples were screen-sorted by the following fractions: leaves (leaves and leaflets, whole or fragmented); wood (branch or bark pieces with a diameter smaller than $2 \mathrm{~cm}$, and fragments), flower + fruits (flowers, inflorescence or organ, and fragments recognized as such, fruits and seeds, whole or fragmented), and the rest (residues smaller than $2 \mathrm{~mm}$, animal-origin and unknown matter) (Proctor et al., 1983). The 25 dried litter fractions were macerated and grouped in 5 composed samples for each soil-litter fraction per site $(n=5)$.

The superficial soil $(0-10 \mathrm{~cm})$ was collected from below the litter layer withdrawn, totalizing 75 samples with $400 \mathrm{~cm}^{2}$ of soil. The 75 soil samples were dried at constant weight in an oven at $60{ }^{\circ} \mathrm{C}$ for $48 \mathrm{~h}$ (Mayor et al., 2014, Severo et al., 2017, Camara et al., 2018). No decarbonation was performed once previous tests verified the absence of inorganic carbon in the soil (Camara et al., 2018). A soil sub-sample was used to determine granulometric fractions (item 3), and another sub-sample was sieved in a $2 \mathrm{~mm}$ mesh and homogenized for isotopic and elemental determination of $\mathrm{C}$ and $\mathrm{N}(\mathrm{n}=25)$ (Telles et al., 2003).

Leaves, organic litter fractions, and soils were dried, ground, weighed (1 mg approximately), and inserted in tin capsules for $\mathrm{C}$ and $\mathrm{N}$ elemental and isotopic determination. All samples were combusted in an elemental analyzer (Flash 2000 Organic Elemental Analyser) which measured elemental concentrations of $\mathrm{C}$ and $\mathrm{N}$; coupled to a stable isotope ratio mass spectrometer (IR-MS Delta V Advantage, Thermo Scientific); and combined with a ConFloIV Interface (Thermo Scientific), which measured the isotopic composition of C and N. Pee Dee Belemnite (PDB) and atmospheric $\mathrm{N}$ were used as standard values for $\mathrm{C}$ and $\mathrm{N}$ analyses, respectively. The values of PDB $\delta^{13} \mathrm{C}$ and atmospheric $\delta^{15} \mathrm{~N}$ are respectively, $0.0111802 \%$ and $0.0036 \%$. The analytical precision was \pm 0.1 for $\delta^{13} \mathrm{C}$ and \pm 0.2 for $\delta^{15} \mathrm{~N}$, and the accuracy for elemental and isotopic compositions were determined by certified Organic Analytical Standard (OAS): Wheat Flour Standard OAS/Isotope Cert. 114858 and Low Organic Content Soil Standard OAS/Isotope Cert. 201613. The values of OAS 114858 were $39.38 \pm 0.19 \%$ for $\mathrm{C} ; 1.36 \pm 0.23 \%$ for $\mathrm{N} ;-27.21 \pm$ $0.13 \%$ for $\delta^{13} \mathrm{C} ; 2.85 \pm 0.17 \%$ for $\delta^{15} \mathrm{~N}$. The values of OAS 201613 were $1.52 \pm 0.02 \%$ for $\mathrm{C}$; $0.13 \pm 0.02 \%$ for $\mathrm{N} ;-27.46 \pm 0.11 \%$ for $\delta^{13} \mathrm{C} ; 6.70 \pm 0.15 \%$ for $\delta^{15} \mathrm{~N}$.

Carbon and nitrogen stable isotope values are reported in "delta" notation as $\delta$ values in parts per thousand $(\%)$.

\section{Determination of the soil granulometric fractions}

PeerJ reviewing PDF | (2019:11:43308:2:0:NEW 25 Apr 2020) 
236

237

238

239

240

241

242

243

244

245

246

247

248

249

250

251

252

253

254

255

256

257

258

259

260

261

262

263

264

265

266

267

268

269

270

271

272

273

274

275

After soil preparation procedures, as aforementioned, sub-samples were sieved, separating $>2$ $\mathrm{mm}$ fractions by sifting in successive intervals. Soil texture (granulometry) was determined in the soil fraction $<2 \mathrm{~mm}$. The methodology used here followed Wentworth (1922) by using a laser diffraction particle analyzer (SALD-3101, Shimadzu).

For precision analytical control, we measured the analytical variation among the analytical triplicates in every 20 samples, with an acceptable variation coefficient inferior to $10 \%$. The accuracy surpassed $90 \%$. Three certified samples supplied by the manufacturer of the equipment (Shimadzu) with differentiated particle size range (JIS class 11, Licopodium and glass beads, DataS3) were used to evaluate the accuracy of the soil granulometric fractions. The limit of detection herein was $0.1 \%$.

The granulometric distribution was compiled by the software SysGran (3.0), and the data was grouped in sand, silt, and clay. The data are expressed in mean and standard error values.

\section{Statistical analysis}

In order to assess the normality in the data, the Shapiro Wilk $(\mathrm{P} \leq 5 \%)$ test was conducted. After assessing the normality and homogeneity, the data underwent parametrical analyses. We analyzed differences between means via ANOVA ( $w o-w a y)$, followed by Tukey test $(\mathrm{P} \leq 5 \%)$. The factors considered herein were the compartments (leaves, litter fractions, and soil), sites, and granulometric fractions; it all aims to understand the interference of eucalyptus permanence time in the $\delta^{13} \mathrm{C}$ and $\delta^{15} \mathrm{~N}$ in leaves, soil and organic litter fractions. The variance analysis was realized in the software Statistica 7.0. We calculated the sand regression coefficient correlations with Sigma Plot 11.0 software package Statistical Package for the Social Sciences (SPSS).

The $\mathrm{C}$ isotopic fractionation during organic matter decomposition was calculated from the difference between the $\delta^{13} \mathrm{C}$ in the soil and the litter fractions. The same was employed to $\mathrm{N}$, by using $\delta^{15} \mathrm{~N}$. We inferred the soil organic matter decomposition based on these calculations.

\section{RESULTS}

\section{The relationship between $C$ and $N$ in the soil-plant system}

The values of $\delta^{13} \mathrm{C}$ and $\delta^{15} \mathrm{~N}$ were higher in the soil $>$ litter $>$ leaves for all studied sites (Fig. 2, DataS4, S5, and S6). We observed a direct relationship between $\delta^{13} \mathrm{C}$ and $\delta^{15} \mathrm{~N}$ (Fig. $2 \mathrm{~A}, \mathrm{C}$, and $\mathrm{E}$ ), and an inverse one between $\delta^{15} \mathrm{~N}$ and $\mathrm{N}$ in all three sites (Fig. $2 \mathrm{~B}, \mathrm{D}$, and $\mathrm{F}$ ).

Regardless of the site, the elemental concentration values for $\mathrm{C}$ and for the $\mathrm{C} / \mathrm{N}$ ratio were respectively distributed: litter fractions $>$ leaves $>$ soil (Table 2). For N, leaves had higher values than litter, being its concentration thus distributed: leaves $>$ litter fractions $>$ soil (Table 2). Significant higher concentrations of $\mathrm{C}$ and $\mathrm{N}$ in the soil were found in the M12 site, when compared with the secondary forest and to the M3 site (Table 2). The $\mathrm{N}$ concentrations of all plant litter fractions were significantly smaller in the two eucalyptus removal sites (M12 and M3, Table 2). The $\mathrm{C} / \mathrm{N}$ ratio in the leaves was higher in the $\mathrm{M} 12$ site. Higher $\mathrm{C} / \mathrm{N}$ ratio values in wood fractions were obtained in the eucalyptus removal sites, in comparison with those of the secondary forest (Table 2). 
276

277

278

279

280

281

282

283

284

285

286

287

288

289

290

291

292

293

294

295

296

297

298

299

300

301

302

303

304

305

306

307

308

309

310

311

312

313

314

315

\section{Decomposition of organic matter in the litter fractions}

There was an enrichment in the ${ }^{13} \mathrm{C}$ between litter fractions and soil in all sites (except for flower and fruit fractions from the secondary forest and the fraction of the rest in the M3 site) (Table 3). On the other hand, there was no enrichment in ${ }^{15} \mathrm{~N}$ in any of the studied sites, being observed only negative values at the time of calculating differences between litter fractions to the soil, for each site (Table 3 ).

There was a negative relationship between $\delta^{15} \mathrm{~N}$ and the $\mathrm{C} / \mathrm{N}$ ratio in the soil (Fig. 3), having the secondary forest the highest value for $\delta^{15} \mathrm{~N}$ in comparison to the eucalyptus removal sites, which did not vary between one another. The soil $\mathrm{C} / \mathrm{N}$ ratio was higher in the most recent eucalyptus removal site (M3) than in the M12 site and the secondary forest (Fig. 3).

The secondary forest soil, where greater values of $\delta^{15} \mathrm{~N}$ were found, presented higher clay content, whereas in the $\mathrm{M} 3$ site, which presented a higher $\mathrm{C} / \mathrm{N}$ ratio, had also featured a more significant amount of sand (Fig. 4, DataS7).

\section{Comparison of $\delta^{13} \mathrm{C}$ and $\delta^{\mathbf{1 5}} \mathrm{N}$ between the compartments and sites}

The $\delta^{13} \mathrm{C}$ values of soil varied from $-26.7 \%$ and $-29.6 \%$ and were consistently higher than those found in leaves and leaf litter fractions (Fig. 5A). The mean soil $\delta^{13} \mathrm{C}$ in the $\mathrm{M} 3$ site was higher than those from both the secondary forest and the M12 site. Significant differences were observed in $\delta^{13} \mathrm{C}$ values of leaves for the M12 site, in comparison to the other two sites; and also with foliar $\delta^{13} \mathrm{C}$ values ranging from $-31.6 \%$ (secondary forest) to $-32.2 \%$ (M3 site). The $\delta^{13} \mathrm{C}$ value of the litter rest fraction in the M3 site was higher than those from the secondary forest and the M12 site (Fig. 5A). In the organic litter, we found that the rest fraction presented the highest $\delta^{13} \mathrm{C}$ value (-23.8 \%o, M3 site), whereas the lowest value was found in the leaf fraction (-31.3\%o, M12 site).

The $\delta^{15} \mathrm{~N}$ values have significantly been higher in the secondary forest samples, when compared with those from the eucalyptus removal sites, regardless of the compartment under analysis (Fig. 5B). Concerning the soil, only positive values were verified, which varied from 2.6 $\%$ to $6.0 \%$. Positive values were also observed for leaves, going from $1.6 \%$ to $2.9 \%$. Negative values of $\delta^{15} \mathrm{~N}$ were registered only in a few litter fractions (rest and wood) from the M12 site.

\section{DISCUSSION}

\section{Variation of carbon isotopic composition $\left(\delta^{13} \mathrm{C}\right)$ in all compartments in the eucalyptus removal sites}

The different $\delta^{13} \mathrm{C}$ variations of compartments between the eucalyptus removal sites and the secondary forest are mainly caused by the difference in the floristic composition, the organic litter input, and the irradiance, which consequently promotes variations in temperature and humidity, thus affecting processes such as assimilation of $\mathrm{C}$ and decomposition. The eucalyptus removal has altered the $\delta^{13} \mathrm{C}$ in every compartment of the managed sites, in comparison with the 
316

317

318

319

320

321

322

323

324

325

326

327

328

329

330

331

332

333

334

335

336

337

338

339

340

341

342

343

344

345

346

347

348

349

350

351

352

353

354

355

secondary forest. The higher $\delta^{13} \mathrm{C}$ values of the residue litter fraction and the soil in the $\mathrm{M} 3$ site reflect the presence, and carbon soil incorporation originated from the photosynthesis of Poaceae species (grassy), with photosynthetic $\mathrm{C}_{4}$ syndrome (Farquhar, 1983). The regenerating understory of tree species in the Atlantic forest in the M3 site was less developed than in the M12 site, possibly on account of the less time for native vegetation to grow and the competition with grassy that is abundant in the M3 site. $\mathrm{C}_{4}$ species present a greater $\delta^{13} \mathrm{C}$ (ranging from -15 $\%$ to $-9 \%$ ) than that of the tree species, which feature photosynthetic $\mathrm{C}_{3}$ syndrome (whose $\delta^{13} \mathrm{C}$ values may vary from -35 to -23\%) (Farquhar et al., 1989; Martinelli et al., 2009). The grassy species contributed to the organic matter onto the soil, raising the $\delta^{13} C$ of soil from the M3 site. In the secondary forest, $\delta^{13} \mathrm{C}$ values were higher in the sequence soil $>$ litter fractions $>$ leaves. A similar pattern was observed in the eucalyptus removal sites, except for the rest litter fraction in the M3 site given the reason aforementioned. The highest soil $\delta^{13} \mathrm{C}$ value, in comparison with the remaining analyzed compartments, may be explained by the fast mineralization of the components with lower $\delta^{13} \mathrm{C}$ values (Gerschlauer et al., 2018). Differences between the $\delta^{13} \mathrm{C}$ from the distinct litter fractions and the $\delta^{13} C$ from the soil are interpreted as consequences of the litter organic matter decomposition (Gerschlauer et al., 2018). During decomposition of litter, fractionation occurs due to the decomposers that preferentially use ${ }^{12} \mathrm{C}$ resulting in ${ }^{13} \mathrm{C}$ enrichment in the remaining soil organic matter (Lichtfouse et al., 1995). The difference in $\delta^{13} \mathrm{C}$ value $\left(\delta^{13} \mathrm{C}\right.$ litter $-\delta^{13} \mathrm{C}$ soil) and the low $\mathrm{C} / \mathrm{N}$ ratio in the soil, observed in the $\mathrm{M} 3$ site, agree with the idea about altering the dynamics of this soil organic matter.

Our results suggest there was organic matter decomposition in every litter fraction and in every site. However, a higher decomposition of the organic matter determined from the $\delta^{13} \mathrm{C}$ in the M3 site was also observed. This result possibly comes from the more significant recent input of vegetal matter into the M3 site soil, as well as the presence of grassy (herbaceous species of rapid decomposition) exclusively in this site. Despite the soil humidity reduction caused by microclimatic alterations from recent handling in the M3 site (such as less humidity, higher irradiance, temperature, and winds), the input increase was enough to evidence more significant decomposition in this particular site.

The highest $\delta^{13} \mathrm{C}$ values found in the M12 site leaves, compared to both secondary forest and the M3 sites, are explained by the fact that this vegetation was formed under greater irradiance, for one year after handling. Sites exposed to more intense irradiance provide the environmental conditions which increase the $\delta^{13} \mathrm{C}$ values within the photosynthesizing tissues (Ehleringer et al., 1986; Domingues et al, 2005; Van der Sleen et al., 2014; Teixeira et al., 2015; Vitoria et al., 2016).

In all sites, the $\delta^{13} \mathrm{C}$ values from the litter leaf fractions were a reflex of the $\delta^{13} \mathrm{C}$ living leaves. However, despite the previous discussion, the influence of the irradiance variation upon $\delta^{13} \mathrm{C}$ values in leaves was not the single cause for $\delta^{13} \mathrm{C}$ values in the litter rest fraction, mainly in the M3 site, where grassy $\left(\mathrm{C}_{4}\right.$ species $)$ enrich the soil with ${ }^{13} \mathrm{C}$. Compared with litter leaves, the remaining fractions ("flowers + fruits" and wood) presented higher $\delta^{13} \mathrm{C}$ values. Variations between the $\delta^{13} \mathrm{C}$ from the source and sink organs have been widely reported, is the enrichment 
356

357

358

359

360

361

362

363

364

365

366

367

368

369

370

371

372

373

374

375

376

377

378

379

380

381

382

383

384

385

386

387

388

389

390

391

392

393

394

395

extension variation of the sink organs $\delta^{13} \mathrm{C}$ dependent on the tissue, species, and environmental conditions (Cernusak et al., 2009; Vitoria et al., 2016).

Among the causes of isotopic variation between source and sink is the variability in the biochemical tissue composition (Cernusak et al., 2009). The leaves present higher cellulose concentrations than do stems and roots which possess more lignin. After eucalyptus removal in the M3 and the M12 sites, the cellulose from leaves decomposed faster than did the lignin from stems, thus changing the soil $\delta^{13} \mathrm{C}$. Cellulose is more enriched with ${ }^{13} \mathrm{C}$ than lignin and lipids (Badeck et al., 2005; Cernusak et al., 2009). Another isotopic difference-contributing factor between source and sink is the isotopic fractionation during night breathing. The $\mathrm{CO}_{2}$ respired in the dark by the aerial part is significantly enriched with ${ }^{13} \mathrm{C}$ when compared with the respiratory substrate pool, whereas the $\mathrm{CO}_{2}$ aspired by the roots does not present enrichment (Klumpp et al., 2005). Moreover, stems grow preferentially at night (Steppe et al., 2005; Saveynet al., 2007).

This is when the exported carbohydrates present higher $\delta^{13} \mathrm{C}$ values. As a consequence, the wood features enrichment of ${ }^{13} \mathrm{C}$ when compared with the leaves. Also, carbohydrates exported during the day present lower $\delta^{13} \mathrm{C}$ values, and supply preferentially for the leaf growth, which occurs faster during the day (Walter \&Schurr, 2005).

However, it is essential to consider that the nature of the site sampling, which occurred under a unique field experimental condition, prevents the replication so as to increase the robustness of this data. In this way, although the data indicate that the presence of grassy and the higher irradiance was determining factors for the alteration of $\delta^{13} \mathrm{C}$ in the analyzed compartments, these data should be regarded cautiously.

\section{Differences in nitrogen isotopic composition $\left(\delta^{15} \mathrm{~N}\right)$ in the soil-plant system related to eucalyptus removal}

The higher $\delta^{15} \mathrm{~N}$ values within the soil-plant system in the secondary forest, compared to the eucalyptus removal sites, can relate to differences in the composition of vegetal species, and in the strategies employed by them regarding the use of the soil nutrients (Viani, 2010). Depending on the variation in the functional diversity among coexisting species, one expects a more efficient use of resources and, in parallel, a reduction in the interspecific competition which, consequently, may increase the ecosystem productivity (Naeem et al., 2009). Some species may also disproportionately contribute to the ecosystem-related processes on account of a high specialization level, as the symbiotic nitrogen fixation (Reed et al., 2008). Although tropical forests have an immense nutrient stock, forest sites under management, in general, may lack nutrients, thus presenting a decrease in these stocks (Bellote et al., 2008). Besides, other factors such as the dominant species, the management period and activity type, the rain cycles and intensity, and the soil properties interfere in the dynamics of nutrients (Bellote et al., 2008).

Our data shows the influence of eucalyptus removal on the superficial soil layer, being the eucalyptus removal sites (M3 and M12), the ones to present lower $\delta^{15} \mathrm{~N}$ in comparison with the secondary forest. Similar $\delta^{15} \mathrm{~N}$ values, to those from the secondary forest, were also found in: other Atlantic forest soils (between -1.2\%o and 6.0\%o) (Viani, 2010; Gragnani, 2014); in the 
396

397

398

399

400

401

402

403

404

405

406

407

408

409

410

411

412

413

414

415

416

417

418

419

420

421

422

423

424

425

426

427

428

429

430

431

432

433

434

435

litter (between -1.8 \%o and $1.8 \%$ ) (Owen, 2013); and in tree leaves from tropical forests (between -3.0\%o and $12.0 \%$ ) (Davidson et al., 2007; Nardoto et al., 2008, Vitória et al. 2018).

Other aspects regarding the retention of $\mathrm{N}$ and the difference in $\delta^{15} \mathrm{~N}$ values in the soil-plant system between the sites should be taken into account. First, there is the $\mathrm{N}$ mobility before the foliar senescence, being its concentration thus distributed: leaves $>$ litter fractions $>$ soil in all the three sites. Second, the differences in soil textures, where more clayey soil was found in the secondary forest than in the eucalyptus removal sites. Clayey soils have greater retaining capacity when compared with sandy ones, especially the $\mathrm{N}$ ammoniacal form (Trumbore \& Camargo, 2009). Clay soils present more intense processes of mineralization, nitrification, and denitrification than do sandy soils in the same region, and that influences the forest productivity and nitrogen availability (Keller et al., 2005). This suggests that $\mathrm{N}$ and $\delta^{15} \mathrm{~N}$ are relatively higher in sites with greater clay concentration (Martinelli et al., 1999; Davidson et al., 2007; Houlton et al., 2007; Craine et al., 2009). Nonetheless, greater water availability also tends to increase $\mathrm{N}$ concentration and $\delta^{15} \mathrm{~N}$ values in leaves and soils (Austin \& Vitousek, 1998; Handley et al., 1999; Amundson et al., 2003; Houlton et al., 2007; Nardoto et al., 2008).

Even though the relationship between clay and soil $\delta^{15} \mathrm{~N}$ might be promote higher $\mathrm{N}$ fractionation (via nitrification, denitrification, and volatilization), in clay-rich soils the relative proportion of $\mathrm{N}$ fractionation might not be directly influenced by clays, but by the stability of clay particles containing ${ }^{15} \mathrm{~N}$-enriched organic matter. As a result of the higher organic matter decomposition and/or higher clay concentrations, it is possible for soils from hotter and/or drier ecosystems to have a greater proportion of $\mathrm{N}$ in the organic matter associated with minerals, as opposed to having a higher proportion of $\mathrm{N}$ that is lost by fractionation processes (Craine et al., 2015).

The lower $\mathrm{C} / \mathrm{N}$ litter ratio limits the $\mathrm{N}$ in the soil, thus raising the organic matter decomposition rates by the biota (Berhe, 2012). The $\mathrm{C} / \mathrm{N}$ ratio in the leaves was greater in the M12 site. Higher $\mathrm{C} / \mathrm{N}$ ratio values in wood fractions were obtained in the eucalyptus removal sites, in comparison with those of the secondary forest. That demonstrates the slow eucalyptus branch wood decomposition compared to that of the native species. Therefore, the secondary forest site, with less $\mathrm{C} / \mathrm{N}$ ratio in the litter, has its $\mathrm{N}$-rich organic compounds consumed rapidly; while the excess of $\mathrm{N}$ is mineralized, increasing hence the $\delta^{15} \mathrm{~N}$ value in the soil. That explains the negative relationship between $\delta^{15} \mathrm{~N}$ and the $\mathrm{C} / \mathrm{N}$ ratio, which is also reported by big-scale evaluations (Amundson et al., 2003; Craine et al., 2015).

Whenever both soil and plant contain high $\delta^{15} \mathrm{~N}$ values, one may infer the presence of organic matter and decomposition activity in the soil, aside from variables such as temperature and gas flow into the atmosphere, which also interfere in the system (Craine et al., 2015). More humid soils (clayey) usually have more nitrogen gases emissions than those sandy soils (Davidson et al., 2000; Keller et al., 2005). Soils with larger quantities of silt and clay present a lower C/N ratio (Stemmer et al., 1998; Christensen, 2001), as observed in the study herein.

The ${ }^{15} \mathrm{~N}$-rich organic matter decomposition, in general, has smaller $\delta^{15} \mathrm{~N}$ values in mountainous ecosystems from tropical forests than do a wide range of tropical forests in low 
436 lands worldwide with average values ranging from $3 \%$ to $14 \%$ (Martinelli et al., 1999;

437 Nardoto et al., 2014). Such low $\delta^{15} \mathrm{~N}$ values were reported in hilly ecosystems and were related 438 to both high concentration of $\mathrm{NO}_{3}{ }^{-}$in soil solution and significant $\mathrm{N}$ lixiviation rates (10 to $15 \mathrm{~kg}$ $439 \mathrm{~N} \mathrm{ha}^{-1}$ year-1) (Gütlein et al., 2016).

440 A significant increase in soil $\delta^{15} \mathrm{~N}$ has also been observed in forests where recent fire events 441 took place (Hemp, 2005; Zech et al., 2011). Vegetation burning may cause loss of gaseous $\mathrm{NO}_{2}$ 442 resulting in depleted values of $\delta^{15} \mathrm{~N}$ (Zech et al., 2011). Some disturbances in the ecosystem 443 (forest fire, selective cutting, and others) trigger changes in the vegetal coat which affects the 444 445 organic matter dynamics, and which may be regarded as variations in the $\mathrm{C} / \mathrm{N}$ ratio in the soil (Saiz et al., 2016). Hence, this work suggests that the high $\delta^{15} \mathrm{~N}$ values in leaves and soil from the secondary forest are a consequence of relatively clay-rich soil combined with a moderate water deficit (Ometto et al., 2006; Nardoto et al., 2008; Quesada et al., 2012) which, consequently, would then lead to greater availability and loss of N (Ometto et al., 2006; Nardoto et al., 2008).

\section{The alteration in vegetation after eucalyptus removal modified the soil properties and furthered the decomposition processes of soil organic matter}

The higher concentration of $\mathrm{C}$ and $\mathrm{N}$ in the soils of the M12 site is associated with two factors mainly: (1) greater eucalyptus litter entry in the system regarding eucalyptus logging, once only eucalyptus tree trunks were removed from the site in order to be commercialized; and (2) longer period since eucalyptus removal in this site, in comparison with the M3 site, which enabled the decomposition and incorporation of the M12 site litter-origin nutrients by the soil. However, the soil C concentration ( $3.3 \%$ ) in the M12 site is among the lowest values reported for tropical forest soils, which vary from $3.0 \%$ (Mazurec, 2003) to $9.0 \%$ (Clevelario Junior, 1996). A similar concentration of elemental $\mathrm{N}$ in the soil, found in the M12 site ( $0.3 \%)$ had been reported by Villela et al. (2001) in superficial soils of eucalyptus crops ( $0.31 \%)$ in the same studied site (Rebio União). The concentration of elemental $\mathrm{N}$ is greater in the leaves than it is in the soil and the litter fractions, which may be explained by the translocation of this mobile element in the plant before the foliar senescence (Aerts \& Chapin, 2000; Satti et al., 2003; Kuang et al., 2010). The great necessity of $\mathrm{N}$ by this organ is due to the photosynthetic process in which many enzymes are entailed, as protein molecules with a catalytic function that contain $\mathrm{N}$ in their structures (Paul \&Pellny, 2003).

The biotic and abiotic conditions fostered the decomposition of ${ }^{13} \mathrm{C}$-enriched compounds in the M3 site. In more sandy-textured soils (M3 site), the organic matter tends to decompose more rapidly, which has less capacity to retain organic matter (Rosell et al., 1996). The more intense presence of sand also favours the lixiviation of more soluble organic compounds, which might dissipate after the litter deposition. Moreover, the greater presence of grassy $\left(\mathrm{C}_{4}\right.$ plants $)$ in the M3 site soil, compared with that of the M12 site, presented a higher value for $\delta^{13} \mathrm{C}$ in the soil because the $\mathrm{C}_{4}$ species showed less isotopic discrimination than did $\mathrm{C}_{3}$ species. From that, the M3 site soil had a higher $\delta^{13} \mathrm{C}$ value (Farquhar, 1983). Studies on the Atlantic forest soils 
476 (Vitorello et al., 1989; Bonde et al., 1992) and the Amazon forest soils (Desjardins et al., 1996)

477 stated that soils with greater clay quantity had higher values for $\delta^{13} \mathrm{C}$. Even so, it was not

478 confirmed by this research, where the $\delta^{13} \mathrm{C}$ value was higher in the M3 site soil, which had a

479 more considerable amount of sand. Certainly, the presence of both grassy species and sandy soil

480 in the M3 site was an influencing factor upon $\delta^{13} \mathrm{C}$ values in this soil.

481 The relationship between the $\mathrm{C} / \mathrm{N}$ ratio and the $\delta^{15} \mathrm{~N}$ may be used as a tool for verifying

482 degradation and stabilization of the soil organic matter in disturbed systems, in comparison with

483 the secondary forest, which has already been observed (Conen et al., 2008). In the present study, 484 the soil $\delta^{15} \mathrm{~N}$ increased along with the decrease in the soil $\mathrm{C} / \mathrm{N}$ ratio soil. Craine and collaborators 485 (2015), studying 6,000 soil samples from 910 sites, had also noted the increase in soil $\delta^{15} \mathrm{~N}$ 486 associated with a decrease in the soil $\mathrm{C} / \mathrm{N}$ ratio, and as a consequence of greater stabilization of 487 the soil organic matter. Soils with high clay content, as it is the case of the secondary forest, also 488 have high soil $\delta^{15} \mathrm{~N}$. The clay and silt fractions are frequently associated with this soil organic 489 matter, thus hampering the decomposition process (Liao et al., 2006).

490 The organic matter with a longer incorporation time into the soil should be a better indicator 491 of the isotopic signature of the decomposer than of the initial input from the fall of branches and 492 plant leaves (Craine et al., 2015). For this reason, the soil organic matter fractions generally 493 show higher $\delta^{15} \mathrm{~N}$ values in humidified soils (Liao et al., 2006; Marin-Spiotta et al., 2009). Liao 494 and collaborators (2006) quantified $\mathrm{C}$ and $\mathrm{N}$ stable isotopes in the soil, as well as their granulometry, in sites where tree species and bushes $\left(\mathrm{C}_{3}\right.$ plants $)$ were replaced by pastures $\left(\mathrm{C}_{4}\right.$ plants). According to these authors, the soils with higher silt and clay fractions were those with higher $\delta^{15} \mathrm{~N}$ values, thus suggesting organic matter stabilization (Marin-Spiotta et al., 2009).

The data presented herein indicate the alteration of $\mathrm{C}$ and $\mathrm{N}$ dynamics in the ecosystem

500

501

502

503

504

505

506

507

508

509

510

511

512

513

514

515 considering land use (presence and subsequent removal of the exotic eucalyptus species from the Atlantic forest fragment). It is important to emphasize the need for caution in the interpretation of these data since there are limitations around this type of experimental design. In studies that make use of real situations in the field, true replicates (sites) are difficult to work. In addition, this study addressed isotopic and soil granulometry analysis. More robust information can be obtained when other indicators and characteristics of vegetation and soil are also analyzed, including functionality attributes, photosynthetic performance, details of soil organic matter composition, among others. However, it is of utmost importance to understand how this exotic species affects the functioning of the ecosystem since eucalyptus has been planted all over the world for commercial or forest restoration purposes, either as monoculture or in symbiotic consortia with native tropical forests (Guariguata et al., 1995; Parrotta et al., 1997; Feyera et al., 2002; Baptista and Rudel, 2006). The substitution of native forest cover by the exotic eucalyptus species has been widely used in order to give financial returns to the landowners (Baptista and Rudel, 2006). In some cases, the economic and environmental purposes are enhanced simultaneously, being the eucalyptus used for its rapid growth in deforested areas (Feyera et al., 2002), facilitating later forest restoration, as seen in plantations of this exotic species in Central America and the Caribbean (Guariguata et al., 1995; Parrotta et al., 1997). 
516 The fact that tropical forests are being the focus of recovery efforts after disturbances and 517 degradation is mainly due to the urgent need to mitigate the consequences of climate change. In

518 this sense, the data presented here are important to improve the understanding of the beneficial 519 effect of the eucalyptus removal in the ecosystem.

520

521

\section{CONCLUSIONS}

522 The removal of the exotic species altered temporally and differently the isotopic and elemental

523 ratios of $\mathrm{C}$ and $\mathrm{N}$ in the different ecosystem compartments due to the floristic composition

524 (appearance and abundant presence of grassy in the M3 site), the alteration in the environmental

525 conditions (irradiance, water availability, and temperature), variations in mineralization and

526 nitrification rates, and of the decomposition and input from the organic litter.

527

528

The soil $\delta^{13} \mathrm{C}$ was higher in the site where the eucalyptus was harvested due to the facilitation of the appearance of grasses with photosynthetic $\mathrm{C}_{4}$ syndrome that were decomposed and incorporated in the soil. Under the environmental conditions studied, such decomposition and

530 incorporation occurred in a short period of time, as the highest values of $\delta^{13} \mathrm{C}$ were observed in

531

532 the area where the eucalyptus was removed three months ago (M3 site), but no later than 12 months (M12 site). Another aspect that contributed to the increase of soil $\delta^{13} \mathrm{C}$ where the

533 eucalyptus was harvested was the higher irradiance input, which increased the values of $\delta^{13} \mathrm{C}$ in

534 the photosynthesizing leaves that will be decomposed afterward.

535

536

The soil $\delta^{15} \mathrm{~N}$ also increased according to the increase in the time of eucalyptus harvesting

537 (higher in the M12 site than in the M3 site), altering the dynamics of the organic matter in this compartment.

538

539

Therefore, the dual-isotope approach was able to generate a more integrated picture of the impact in the ecosystem after the eucalyptus removal in this secondary Atlantic forest. Finally,

540 this tool should be considered as an option for future eucalyptus removal studies, taking into account the particularity of the data generated given the absence of sample replicas.

542 Nevertheless, our data were able to detect the influence of this exotic species on the isotopic

543 changes of $\mathrm{C}$ and $\mathrm{N}$ in all compartments of the ecosystem.

544

\section{ACKNOWLEDGEMENTS}

546 The authors thank the support from the Laboratory of Environmental Sciences at the Graduate

547 Programme in Ecology and Natural Resources of the Universidade Estadual do Norte

548 Fluminense Darcy Ribeiro; and the União Biological Reserve. The authors thank José Luiz Alves

549 da Silva for preparing Fig. 1. Carlos E. Rezende thanks the financial support of CNPq

550 (305217/2017-8) and FAPERJ (E-26/202.916/2017). Angela P. Vitória thanks the financial

551 support of CNPq (301169/2016-0). This study was financed by the Brazilian Federal Agency for

552 Support and Assessment of Post-graduate Education -Brazil (CAPES)-Finance Code 001. The

553 authors thank Dr. José Luiz Alves da Silva for preparing Fig. 1. There was no additional external

554 funding reveived for this study.

555 


\section{REFERENCES}

557 Aerts R, Chapin FS. 2000. The mineral nutrition of wild plants revisited: a re-evaluation of

558

559

560

561

562

563

564

565

566

567

568

569

570

571

572

573

574

575

576

577

578

579

580

581

582

583

584

585

586

587

588

589

590

591

592

593 processes and patterns. Advances in Ecological Research 30:1-67 DOI 10.1016/S00652504(08)60016-1.

Alvares CA, Stape JL, Sentelhas PC, De Moraes Gonçalves JL, Sparovek G. 2013. Köppen's climate classification map for Brazil. Meteorologische Zeitschrift 22:711-728 DOI 10.1127/0941-2948/2013/0507.

Amundson R, Austin AT, Schuur EAG, Yoo K, Matzek V, Kendall C, Uebersax A, Brenner D, Baisden WT. 2003. Global patterns of the isotopic composition of soil and plant nitrogen. Global Biogeochemical Cycles 17:1031-1042 DOI 10.1029/2002GB001903.

Austin AT, Vitousek PM. 1998. Nutrient dynamics on a precipitation gradient in Hawaii. Oecologia 113:519-529 DOI 10.1007/s004420050405.

Badeck FW, Tcherkez G, Nogués S, Piel C, Ghashghaie J. 2005. Post-photosynthetic fractionation of stable carbon isotopes between plant organs - A widespread phenomenon. Rapid Communications in Mass Spectrometry 19:1381-1391DOI 10.1002/rcm.1912.

Baptista S, Rudel TK. 2006. A re-emerging Atlantic forest? Urbanization, industrialization and the forest transition in Santa Catarina, southern Brazil. Environmental Conservation 3:195-202 DOI 10.1017/S0376892906003134.

Bayer C, Martin Neto L, Mielniczuk J, Pavinato A. 2004. Carbon storage in labile fractions of soil organic matter in a tropical no-tillage Oxisol. Pesquisa Agropecuária Brasileira 39:677-683 DOI 10.1590/S0100-204X2004000700009.

Bellote AFJ, Dedecek RA, Silva HD. 2008. Mineral nutrients, biomass and litter deposition on Eucalyptus plantation under different residue management. Pesquisa Florestal Brasileira 56:31-41 DOI 10.4336/2012.pfb.56.31.

Berhe AA. 2012. Decomposition of organic substrates at eroding vs. depositional landform positions. Plant and Soil 350:261-280 DOI 10.1007/s11104-011-0902-z.

Boeger MRT, Wisniewski C, Reissmann CB. 2005. Leaf nutrient content of tree species from three successional stages of tropical rain forest in south Brazil. Acta Botanica Brasilica 19:167-181 DOI 10.1590/S0102-33062005000100017.

Bonde TA, Christensen BT, Cerri CC. 1992. Dynamics of soil organic matter as reflected by natural ${ }^{13} \mathrm{C}$ abundance in particle size fractions of forested and cultivated oxisols. Soil Biology and Biochemistry 24:275-277 DOI 10.1016/0038-0717(92)90230-U.

Brockerhoff EG, Jactel H, Parrotta JA, Quine CP, Sayer J. 2008. Plantation forests and biodiversity: Oxymoron or opportunity? Biodiversity and Conservation 17:925-951 DOI 10.1007/s10531-008-9380-x.

Bustamante MMC, Martinelli LA, Silva DA, Camargo PB, Klink CA, Domingues TF, Santos RV. 2004. ${ }^{15} \mathrm{~N}$ Natural abundance in woody plants and soils of Central Brazilian savannas (Cerrado). Ecological Applications 14:200-213 DOI 10.1890/01-6013. 
594

595

596

597

598

599

600

601

602

603

604

605

606

607

608

609

610

611

612

613

614

615

616

617

618

619

620

621

622

623

624

625

626

627

628

629

630

631

Camara R., Silva VD, Delaqua GCG, Lisbôa CP, Villela DM. 2018. Relationship among secondary succession, soil and litter in a biological reserve in Rio de Janeiro state, Brazil. Ciência Florestal 28(2):674-686.

Cernusak L, Tcherkez G, Keitel C, Cornwell W, Santiago L, Knohl A, Barbour M, Williams D, Reich P, Ellsworth D, Dawson T, Griffiths H, Farquhar G, Wright I. 2009. Why are non-photosynthetic tissues generally ${ }^{13} \mathrm{C}$ enriched compared with leaves in $\mathrm{C}_{3}$ plants? Review and synthesis of current hypotheses. Functional Plant Biology 36:199213 DOI 10.1071/FP08216.

Christensen BT. 2001. Physical fractionation of soil and structural and functional complexity in organic matter turnover. European Journal of Soil Science 52:345-353 DOI 10.1046/j.1365-2389.2001.00417.x.

Clevelario Júnior J. 1996. Carbon and mineral distribution in a low-montane humid tropical forest ecosystem. Tese de Doutorado. Universidade Federal de Viçosa.

Conen F, Zimmermann M, Leifeld J, Seth B, Alewell C. 2008. Relative stability of soil carbon revealed by shifts in $\delta^{15} \mathrm{~N}$ and C:N ratio. Biogeosciences Discussion 4:2915-2928 DOI 10.5194/bgd-4-2915-2007.

Costa GS, Gama-Rodrigues AC, Cunha GM. 2005. Decomposition and nutrient release from leaf litter of Eucalyptus grandis in plantations and regrowth systems in northern Rio de Janeiro state, Brazil. Revista Árvore 29:563-570 DOI 10.1590/S010067622005000400008.

Craine J, Craine JM, Elmore AJ, Aidar MPM, Bustamante M, Dawson TE, Hobbie EA, Kahmen A, Mack MC, Mclauchlan KK, Michelsen A, Nardoto GB, Pardo LH, Peñuelas J, Reich PB, Schuur EAG, Stock WD, Templer PH, Virginia RA, Welkwer JM, Wright IJ. 2009. Global patterns of foliar nitrogen isotopes and their relationships. New Phytologist 183:980-992 DOI 10.1111/j.1469-8137.2009.02917.x.

Craine JM, Brookshire ENJ, Cramer MD, Hasselquist NJ, Koba K, Marin-Spiotta E, Wang L. 2015. Ecological interpretations of nitrogen isotope ratios of terrestrial plants and soils. Plant and Soil 396:1-26 DOI 10.1007/s11104-015-2542-1.

Davidson EA, Keller M, Erickson HE, Verchot LV, Veldkamp E. 2000. Testing a conceptual model of soil emissions of nitrous and nitric oxides. BioScience 50:667-680 DOI 10.1641/0006-3568(2000)050[0667:TACMOS]2.0.CO;2.

Davidson EA, Carvalho CJR, Figueira AM, Ishida FY, Ometto JPHB, Nardoto GB, Saba RT, Hayashi SN, Leal EC, Vieira ICG, Martinelli LA. 2007. Recuperation of nitrogen cycling in Amazonian forests following agricultural abandonment. Nature 447:995-999 DOI 10.1038/nature05900.

Dawson TE, Mambelli S, Plamboek AH, Templer PH, Tu KP. 2002. Stable isotopes in plant ecology. Annual Review of Ecology, Evolution, and Systematics 33:507-559 DOI 10.1146/annurev.ecolsys.33.020602.095451.

Peer) reviewing PDF | (2019:11:43308:2:0:NEW 25 Apr 2020) 
632 Desjardins T, Filho Carneiro A, Mariotti A, Chauvel A, Girardin C. 1996. Changes of the

633

634

635

636

637

638

639

640

641

642

643

644

645

646

647

648

649

650

651

652

653

654

655

656

657

658

659

660

661

662

663

664

665

666

667

668

669

670

671 forest-savanna boundary in Brazilian Amazonia during Holocene revealed by stable isotope ratios of soil organic carbon. Oecologia 108:749-756 DOI 10.1007/BF00329051.

Diekow J, Mielniczuk J, Knicker H, Bayer C, Dick DP, Kögel-Knabner I. 2005. Soil C and $\mathrm{N}$ stocks as affected by cropping systems and nitrogen fertilization in a southern Brazil Acrisol managed under no-tillage for 17 years. Soil \& Tillage Research 81:87-95 DOI 10.1016/j.still.2004.05.003.

Domingues TF, Berry JA, Martinelli LA, Ometto JPHB, Ehleringer JR. 2005. Parameterization of canopy structure and leaf-level gas exchange for an eastern Amazonian tropical rain forest (Tapajós National Forest, Pará, Brazil). Earth Interactions 9:1-23 DOI 10.1175/EI149.1.

dos Santos HG, Jacomine PKT, dos Anjos LHC, Oliveira VA, Lumbreras JF, Coelho MR, Almeida JA, de Araújo Filho JC, Cunha TJF. 2018. Brazilian Soil Classification System. $5^{\circ}$ Ed. http://ainfo.cnptia.embrapa.br/digital/bitstream/item/181678/1/SiBCS2018-ISBN-9788570358219-english.epub

Dutta RK, Agrawal M. 2001. Litter, litter decomposition and nutrient release in five exotic plant species planted on coal mine spoils. Pedobiologia 45:298-312 DOI 10.1078/00314056-00088.

Ehleringer JR, Field CB, Lin ZF, Kuo CY. 1986. Leaf carbon isotope ratio and mineral composition in subtropical plants along an irradiance cline. Oecologia 70:520-526DOI 10.1007/BF00379898.

Empresa Brasileira de Pesquisa Agropecuária - EMBRAPA. 1999. Centro Nacional de Pesquisa de Solos. Sistema brasileiro de classificação de solos. Rio de Janeiro. 412p.

Evaristo VT, Braga JMA, Nascimento MT. 2011. Atlantic Forest regeneration in abandoned plantations of eucalypt (Corymbia citriodora (Hook .) K .D . Hill and L. A. S. Johnson) in Rio de Janeiro, Brazil. Interciencia 36:431-436.

Farquhar G, O'Leary M, Berry J. 1982. On the relationship between carbon isotope discrimination and the intercellular carbon dioxide concentration in leaves. Australian Journal of Plant Physiology 9:121-137 DOI 10.1071/PP9820121.

Farquhar GD. 1983. On the nature of carbon isotope discrimination in $\mathrm{C}_{4}$ species. Australian Journal of Plant Physiology 10:205-226 DOI 10.1071/PP9830205.

Farquhar GD, Ehleringer JR, Hubick KT. 1989. Carbon isotope discrimination and photosynthesis. Annual Review of Plant Physiology and Plant Molecular Biology 40:503537 DOI 10.1146/annurev.pp.40.060189.002443.

Feyera S, Beck E, Lüttge U. 2002. Exotic trees as nurse-trees for the regeneration of natural tropical forests. Trees 16:245-249 DOI 10.1007/s00468-002-0161-y.

Freitas HA, Pessenda LCR, Aravena R, Gouveia SEM, Ribeiro AS, Boulet R. 2001. Late Quaternary vegetation dynamics in the southern Amazon Basin inferred from carbon isotopes in soil organic matter. Quaternary Research 55:39-46 DOI 10.1006/qres.2000.2192.

Peer] reviewing PDF | (2019:11:43308:2:0:NEW 25 Apr 2020) 
672 Gama-Rodrigues EF, Barros NF, Gama-Rodrigues AC, Santos GA. 2005. Carbon, nitrogen

673

674

675

676

677

678

679

680

681

682

683

684

685

686

687

688

689

690

691

692

693

694

695

696

697

698

699

700

701

702

703

704

705

706

707

708

709 and activity of microbial biomass in soil under eucalypt plantations. Revista Brasileira de Ciência do Solo 29:893-901 DOI 10.1590/S0100-06832005000600007.

Gama-Rodrigues EF, Barros NF, Vianna AP, Santos GA. 2008. Microbial biomass and activity in soil and forest litter of eucalyptus plantations and native vegetation in Southeastern Brazil. Revista Brasileira de Ciência do Solo 32:1489-1499 DOI 10.1590/S0100-06832008000400013.

Gerschlauer F, Saiz G, Schellenberger DC, Michael K, Dannenmann M, Kiese R. 2018. Stable carbon and nitrogen isotopic composition of leaves, litter, and soils of various tropical ecosystems along an elevational and land-use gradient at Mount Kilimanjaro, Tanzania. Biogeosciences 16:409-424DOI 10.5194/bg-2018-407.

Gragnani JG. 2014. Nitrogen dynamics in two naturally regenerated pasture áreas in Serra do Mar State Park - Santa Virginia nucleus. Dissertação de Mestrado, Universidade de São Paulo.

Guariguata M, Rheingans R, Montagnini F. 1995. Early woody invasion under tree plantations in Costa Rica: implications for forest restoration. Restoration Ecology 3:252260 DOI 10.1111/j.1526-100X.1995.tb00092.x

Guo L, Sims RE. 1999. Litter production and nutrient return in New Zealand eucalypt shortrotation forests: implications for land management. Agriculture, Ecosystems \& Environment 73:93-100 DOI 10.1016/S0167-8809(99)00006-7.

Gütlein A, Gerschlauer F, Kikoti I, Kiese R. 2016. Impacts of climate and land use on $\mathrm{N}_{2} \mathrm{O}$ and $\mathrm{CH}_{4}$ fluxes from tropical ecosystems in the Mt. Kilimanjaro region, Tanzania. Global Change Biology 38:42-49 DOI 10.1111/gcb.13944.

Handley LL, Austin AT, Robinson D, Scrimgeour CM, Raven JA, Heaton THE, Schmidt S, Stewart GR. 1999. The ${ }^{15} \mathrm{~N}$ natural abundance $\left(\delta^{15} \mathrm{~N}\right)$ of ecosystem samples reflects measures of water availability. Australian Journal of Plant Physiology 26:185-199 DOI 10.1071/PP98146.

Hemp A. 2005. Climate change-driven forest fires marginalize the impact of ice cap wasting on Kilimanjaro. Global Change Biology 11:1013-1023 DOI 10.1111/j.13652486.2005.00968.x.

Högberg P. 1997. ${ }^{15} \mathrm{~N}$ natural abundance in soil-plant systems. New Phytologist 137:179-203 DOI 10.1046/j.1469-8137.1997.00808.x.

Houghton RA. 2005. Aboveground forest biomass and the global carbon balance. Global Change Biology 11:945-958 DOI 10.1111/j.1365-2486.2005.00955.x.

Houlton BZ, Sigman DM, Schuur EG, Hedin LO. 2007. A climate-driven switch in plant nitrogen acquisition within tropical forest communities. Proceedings of the National Academy of Sciences of the United States of America 104:8902-8906 DOI 10.1073/pnas.0609935104. 
710

711

712

713

714

715

716

717

718

719

720

721

722

723

724

725

726

727

728

729

730

731

732

733

734

735

736

737

738

739

740

741

742

743

744

745

746

747

Keller M, Varner R, Silva H, Asner GP. 2005. Soil-atmosphere exchange of nitrous oxide, nitric oxide, methane, and carbon dioxide in logged and undisturbed forest in the Tapajos National Forest, Brazil. Earth Interactions 9:1-28 DOI 10.1175/EI125.1.

Klumpp K, Schäufele R, Lötscher M, Lattanzi FA, Feneis W, Schnyder H. 2005. C-isotope composition of $\mathrm{CO}_{2}$ respired by shoots and roots: Fractionation during dark respiration? Plant, Cell \& Environment 28:241-250DOI 10.1111/j.1365-3040.2004.01268.x.

Kuang YW, Wen DZ, Li J, Sun FF, Hou EQ, Zhou GY, Zhang DQ, Huang LB. 2010. Homogeneity of delta15N in needles of Masson pine (Pinus massoniana L.) was altered by air pollution. Environmental Pollution 158:1963-1967 DOI 10.1016/j.envpol.2009.10.028.

Le Roux X, Baric T, Sinoquet H, Genty B, Piel C, Mariotti A, Girardin C, Richard. 2001. Spatial distribution of leaf water-use efficiency and carbon isotope discrimination within an isolated tree crown. Plant, Cell and Environment 24: 1021-1032. DOI 10.1046/j.00168025.2001.00756.x

Liao JD, Boutton TW, Jastrow JD. 2006. Organic matter turnover in soil physical fractions following woody plant invasion of grassland: Evidence from natural ${ }^{13} \mathrm{C}$ and ${ }^{15} \mathrm{~N}$. Soil Biology and Biochemistry 38:3197-3210 DOI 10.1016/j.soilbio.2006.04.004.

Lichtfouse E, Dou S, Girardin C, Grably M, BalesdentJ, Behar F, Vanderbroucke, M. 1995. Unexpected 13C-enrichment of organic components from wheat crop soils: evidence for the in situ origin of soil organic matter. Organic geochemistry 23: 865-868. DOI 10.1016/0146-6380(95)80009-G.

Lorenzi H. 2000. Árvores brasileiras: manual de identificação e cultivo de plantas arbóreas nativas do Brasil. Nova Odessa: Instituto Plantarum p. 256.

Mayor JR, Wright SJ, Schuur EAG, Brooks ME, Turner, BL. 2014. Stable nitrogen isotope patterns of trees and soils altered by long-term nitrogen and phosphorus addition to a lowland tropical rainforest. Biogeochemistry 119: 293-306.

Mardegan SF, Nardoto GB, Higuchi N, Moreira MZ, Martinelli LA. 2009. Nitrogen availability patterns in white-sand vegetations of central Brazilian Amazon. Trees 23:479488 DOI 10.1007/s00468-008-0293-9.

Marin-Spiotta E, Silver WL, Swanston CW, Ostertag R. 2009. Soil organic matter dynamics during 80 years of reforestation of tropical pastures. Global Change Biology 15:15841597DOI 10.1111/j.1365-2486.2008.01805.x.

Martinelli LA, Ometto JPHB, Ferraz ES, Victoria RL, Camargo PB, Moreira MZ. 2009. Desvendando questões ambientais com isótopos estáveis. Oficina de Textos, São Paulo. $144 p$.

Martinelli LA, Piccolo MC, Townsend AR, Vitousek PM, Cuevas E, McDowell W, Robertson GP, Santos OC, Treseder K. 1999. Nitrogen stable isotopic composition of leaves and soil: Tropical versus temperate forests. Biogeochemistry 46:45-65 DOI 10.1007/BF01007573. 
748

749

750

751

752

753

754

755

756

757

758

759

760

761

762

763

764

765

766

767

768

769

770

771

772

773

774

775

776

777

778

779

780

781

782

783

784

785

786

787

Mazurec AP. 2003. Changes in organic matter and soil fertility under different land use: a region of northern fluminense forest. Dissertação. Universidade Estadual do Norte Fluminense Darcy Ribeiro.

Miranda CC, Canellas LP, Nascimento MT. 2007. Quality of soil organic matter in fragments of Atlantic forest and abandoned eucalyptus plantations. Revista Brasileira de Ciências do Solo 31:905-916. DOI 10.1590/S0100-06832007000500008.

Morellato LPC, Haddad CFB. 2000. Introduction: the Brazilian Atlantic Forest. Biotropica 32:786-792 DOI 10.1646/0006-3606(2000)032[0786:ITBAF]2.0.CO;2.

Naeem S, Bunker DE, Hector A, Loreau M,Perrings C. 2009. Biodiversity, ecosystem functioning, and perspective, human wellbeing: An ecological and economic. Oxford University Press 384p.DOI 10.1093/acprof:oso/9780199547951.001.0001.

Nardoto GB, Ometto JPHB, Ehleringer JR, Higuchi N, Bustamante MMDC, Martinelli LA. 2008. Understanding the influences of spatial patterns on $\mathrm{N}$ availability within the Brazilian Amazon forest. Ecosystems 11:1234-1246DOI 10.1007/s10021-008-9189-1.

Nardoto GB, Quesada CA, Patiño S, Saiz G, Baker TR, Schwarz M, Schrodt F, Feldpausch TR, Domingues TF, Marimon BS, Marimon Junior BH, Vieira ICG, Silveira M, Bird MI, Phillips OL, Lloyd J, Martinelli LA. 2014. Basin-wide variations in Amazon forest nitrogen-cycling characteristics as inferred from plant and soil ${ }^{15} \mathrm{~N}:{ }^{14} \mathrm{~N}$ measurements. Plant Ecology \& Diversity 7:173-187DOI 10.1080/17550874.2013.807524.

McDowell NG, Bond BJ, Dickman LT, Ryan MG, Whitehead D. 2011. Relationships Between Tree Height and Carbon Isotope Discrimination in Size- and Age-Related Changes in Tree Structure and Function. Editors. Meinzer FC, Lachenbruch B, Dawson TE. Ed. Springer. https://link.springer.com/chapter/10.1007/978-94-007-1242-3_10.

Ometto JHB, Ehleringer JR, Domingues TF, Berry JA, Ishida FY, Mazzi E, Higuchi N, Flanagan LB, Nardoto GB, Martinelli LA. 2006. The stable carbon and nitrogen isotopic composition of vegetation in tropical forests of the Amazon Basin, Brazil. Biogeochemistry 79:251-274DOI 10.1007/978-1-4020-5517-1_12.

Owen JS. 2013. Stable nitrogen isotopes in a forested watershed in Taiwan. Journal of Forest Science 29:116-124 DOI 10.7747/JFS.2013.29.2.116.

Parrotta JA, Turnbull JW, Jones N. 1997. Catalyzing native forest regeneration on degraded tropical lands. Forest Ecologyand Management 99:1-7 DOI 10.1016/S03781127(97)00190-4.

Paul MJ, Pellny TK. 2003. Carbon metabolite feedback regulation of leaf photosynthesis and development. Journal of Experimental Botany54:539-547 DOI 10.1093/jxb/erg052.

Pregitzer KS, Euskirchen ES. 2004. Carbon cycling and storage in world forests: Biome patterns related to forest age. Global Change Biology 10:2052-2077 DOI 10.1111/j.13652486.2004.00866.x.

Proctor J, Anderson JM, Chai P, Vallack HW. 1983. Ecological studies in four contrasting lowland rain forests in Gunung Mulu National Park, Sarawak: I. Forest Environment, structure and floristics. Journal of Ecology 71:237-260 DOI 10.2307/2259975. 
788

789

790

791

792

793

794

795

796

797

798

799

800

801

802

803

804

805

806

807

808

809

810

811

812

813

814

815

816

817

818

819

820

821

822

823

824

825

826

Quesada CA, Phillips OL, Schwarz M, Czimczik CI, Baker TR, Patiño S, Fyllas NM, Hodnett MG, Herrera R, Almeida S, Alvarez Dávila E, Arneth A, Arroyo L, Chao KJ, Dezzeo N, Erwin T, Di Fiore A, Higuchi N, Honorio Coronado E, Jimenez EM, Killeen T, Lezama AT, Lloyd G, Löpez-González G, Luizão FJ, Malhi Y, Monteagudo A, Neill DA, Núñez Vargas P, Paiva R, Peacock J, Peñuela MC, Peña Cruz A, Pitman N, Priante Filho N, Prieto A, Ramírez H, Rudas A, Salomão R, Santos AJB, Schmerler J, Silva N, Silveira M, Vásquez R, Vieira I, Terborgh J, Lloyd J. 2012. Basin-wide variations in Amazon forest structure and function are mediated by both soils and climate. Biogeosciences 9:2203-2246 DOI 10.5194/bg-9-2203-2012.

Reed SC, Cleveland CC, Townsend A. 2008. Tree species control rates of free-living nitrogen fixation in tropical rain forest. Ecology 89:2924-2929DOI 10.1890/07-1430.1.

Rezende JLP, Garcia QS, Scotti MR. 2001. Laboratory decomposition of Dalbergia nigra All. Ex. Benth and Eucalyptus grandis W. Hill Ex. Maiden leaves in forest and eucalypt plantation soils. Acta Botanica Brasilica 15:305-312DOI 10.1590/S010233062001000300002 .

Rosell RA, Galantini JA, Iglesias JO. 1996. Organic carbon changes in soil fractions of two texturally-different Haplustolls under cultivation, in: Humic Substances in Soil and Water Environments. pp. 161-162.

Saiz G, Wandera FM, Pelster DE, Ngetich W, Okalebo JR, Rufino MC,Butterbach-Bahl K. 2016. Long-term assessment of soil and water conservation measures (Fanya-juu terraces) on soil organic matter in South Eastern Kenya. Geoderma 274:1-9 DOI 10.1016/j.geoderma.2016.03.022.

Satti P, Mazzarino MJ, Gobbi M, Funes F, Roselli L, Fernandez H. 2003. Soil N dynamics in relation to leaf litter quality and soil fertility in north-western Patagonian forests. Journal of Ecology 91:173-181DOI 10.1046/j.1365-2745.2003.00756.x.

Saveyn A, Steppe K, Lemeur R. 2007. Daytime depression in tree stem $\mathrm{CO}_{2}$ efflux rates: Is it caused by low stem turgor pressure? Annals of Botany 99:477-485 DOI 10.1093/aob/mcl268.

Severo FF, Aita NT, Marques LG, Silva LS. 2017. Isotopic abundance of ${ }^{13} \mathrm{C}$ and contribution of eucalyptus biomass to soil organic matter conversion. Ciência Rural 47(4), e20150900.

Stemmer M, Gerzabek MH, Kandeler E. 1998. Organic matter and enzyme activity in particle-size fractions of soils obtained after low-energy sonication. Soil Biology and Biochemistry30:9-17 DOI 10.1016/S0038-0717(97)00093-X.

Steppe K, Pauw DJWDE, Lemeur R, Vanrolleghem A. 2005. A mathematical model linking tree sap flow dynamics to daily stem diameter fluctuations and radial stem growth. Tree 26: 257-273DOI 10.1093/treephys/26.3.257.

Teixeira MC, Vieira TO, Almeida TCM, Vitória AP. 2015. Photoinhibition in Atlantic forest native species: short-term acclimative responses to high irradiance. Theoretical and Experimental Plant Physiology27:183-189 DOI 10.1007/s40626-015-0043-5. 
827

828

829

830

831

832

833

834

835

836

837

838

839

840

841

842

843

844

845

846

847

848

849

850

851

852

853

854

855

856

857

858

859

860

861

862

863

864

865

866

Teixeira MC, Trindade FG, Da Cunha M, Rezende CE, Vitória AP. 2018. Ultrastructural and functional chloroplast changes promoting photoacclimation after forest management in a tropical secondary forest. Forest Ecology and Management 428:27-34 DOI 10.1016/j.foreco.2018.06.032.

Telles ECC, Camargo PB, Martinelli LA, Trumbore SE, Costa ES, Santos J, Higuchi N, Oliveira JrRC. 2003. Influence of soil texture on carbon dynamics and storage potential in tropical forest soils of Amazonia. Global Biogeochemical Cycles 17:1-12 DOI 10.1029/2002GB001953.

Trumbore S, Camargo PB. 2009. Soil carbon dynamics. In: Keller, M.; Bustamante, M.; Gash, J.; Dias, P.S. (Ed.). Amazonia and Global Change. Washington: American Geophysical Union p. 451-462 DOI 10.1029/2009GM000882.

Vallano DM, Sparks JP. 2013. Foliar $\delta^{15} \mathrm{~N}$ is affected by foliar nitrogen uptake, soil nitrogen, and mycorrhizae along a nitrogen deposition gradient. Oecologia 172:47-58 DOI 10.1007/s00442-012-2489-3.

Van der Sleen P, Soliz-Gamboa CC, Helle G, Pons TL, Anten NPR, Zuidema PA. 2014. Understanding causes of tree growth response to gap formation: ${ }^{13} \mathrm{C}$-values in tree rings reveal a predominant effect of light. Trees: Structure and Function 28:439-448 DOI 10.1007/s00468-013-0961-2.

VianiRAG. 2010. Functional traits and the distribution of cerradão and seasonally dry forest species. Tese de Doutorado, Universidade Estadual de Campinas.

Villela DM, Nascimento MT, Mazurec AP, Gonçalvez GM, Rezende CE. 2001. Soil chemical properties under Eucalyptus citriodora plantations of different ages after a 9-year period of abandonment in União Biological Reserve, Rio de Janeiro State, Brazil, Symposium A Quarterly Journal In Modern Foreign Literatures. 3-5p.

Vitorello VA, Cerri CC, Andreux F, Feller C, Victória RL. 1989. Organic matter and natural Carbon-13 distribution in forested and cultivated oxisols. Soil Science Society of America Journal 53:773-778 DOI 10.2136/sssaj1989.03615995005300030024x.

Vitória AP, Vieira TDO, Camargo PDB, Santiago LS. 2016. Using leaf $\delta^{13} \mathrm{C}$ and photosynthetic parameters to understand acclimation to irradiance and leaf age effects during tropical forest regeneration. Forest Ecology and Management 379:50-60 DOI 10.1016/j.foreco.2016.07.048.

Vitória AP, Ávila-Lovera E, Vieira TO, Couto-Santos APL, Pereira TJ, Funch LS, Freitas L, Miranda LDAP, Rodrigues PJFP, Rezende CE, Santiago LS. 2018. Isotopic composition of leaf carbon $\left(\delta^{13} \mathrm{C}\right)$ and nitrogen $\left(\delta^{15} \mathrm{~N}\right)$ of deciduous and evergreen understorey trees in two tropical Brazilian Atlantic forests. Journal of Tropical Ecology 34:145-156 DOI 10.1017/S0266467418000093.

Vitória AP, Alves LF, Santiago LS. 2019. Atlantic forest and leaf traits: an overview. Trees DOI 10.1007/s00468-019-01864-z.

Vitousek P, Sanford RLJ. 1986. Nutrient cycling in moist tropical forest. Annual Review of Ecology and Systematics 17:137-167 DOI 10.1146/annurev.es.17.110186.001033. 
867 Vitousek PM, Matson PA. 1984. Mechanisms of nitrogen retention in forest ecosystems: a field

868

869

870

871

872

873

874

875

876

877

878 experiment. Science 225:51-52 DOI 10.1126/science.225.4657.51.

Walter A, Schurr U. 2005. Dynamics of leaf and root growth: Endogenous control versus environmental impact. Annals of Botany 95:891-900 DOI 10.1093/aob/mci103.

Wentworth CK. 1922. A scale of grade and class terms for clastic sediments. The Journal of Geology 30:377-392 DOI 10.1086/622910.

Wright SJ, Muller-Landau HC. 2006. The future of tropical forest species. Biotropica 38:287301 DOI 10.1111/j.1744-7429.2006.00154.x.

Zech M, Bimüller C, Hemp A, Samimi C, Broesike C, Hörold C, Zech W. 2011. Human and climate impact on ${ }^{15} \mathrm{~N}$ natural abundance of plants and soils in high-mountain ecosystems: A short review and two examples from the Eastern Pamirs and Mt. Kilimanjaro. Isotopes in Environmental and Health Studies 47:286-296 DOI 10.1080/10256016.2011.596277. 
Figure 1

Geographic map indicating the secondary forest and other two sites where eucalyptus had been removed at different times

Geographic map indicating the secondary forest and other two sites where eucalyptus had been removed in different times: 12 and 3 months ago (M12 and M3, respectively), União Biological Reserve, Brazil.

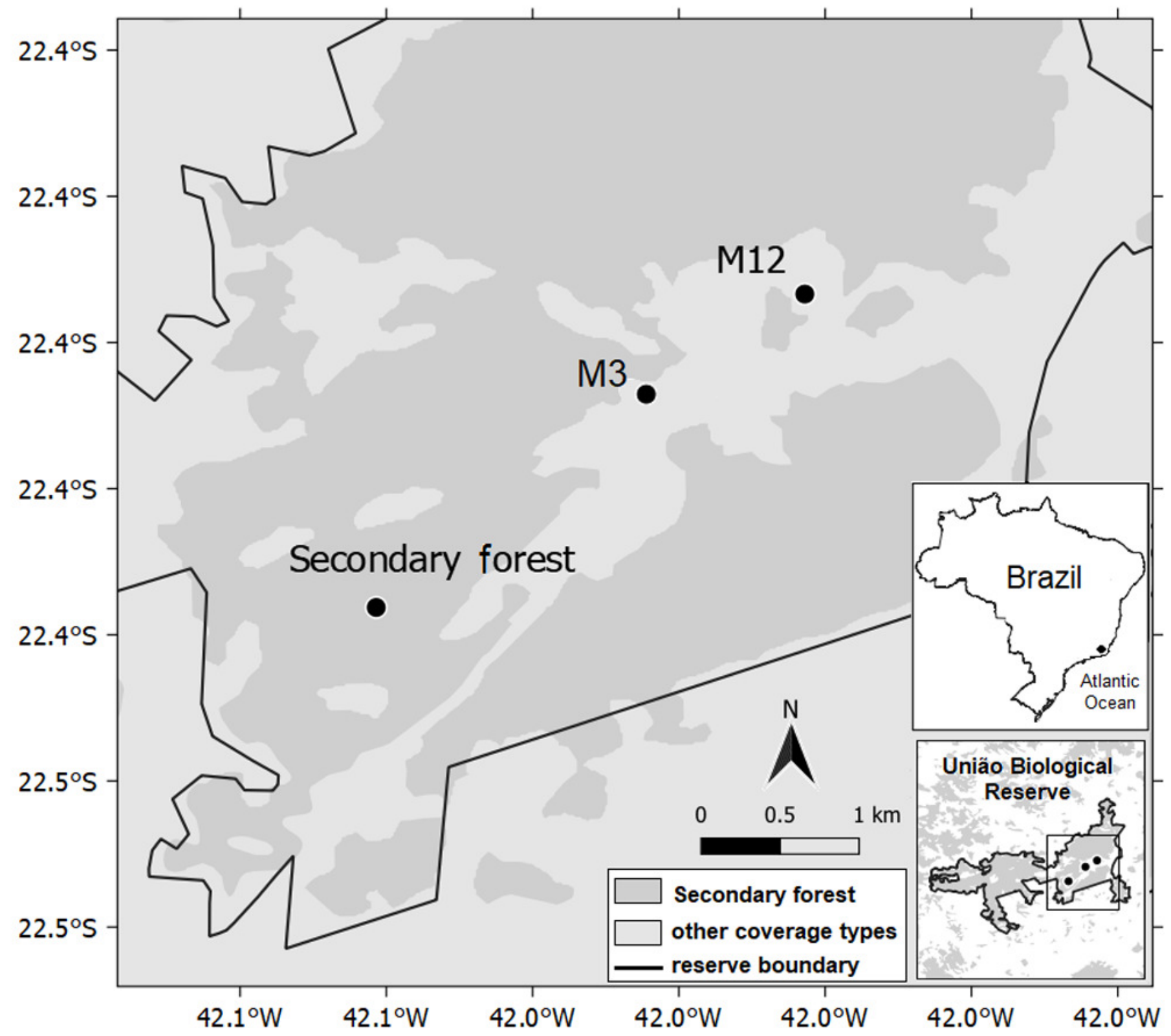




\section{Figure 2}

Linear regression between nitrogen $\left(\delta^{15} \mathrm{~N}\right)$ and carbon $\left(\delta^{13} \mathrm{C}\right)$ isotopic composition and between $\delta^{13} \mathrm{C}$ and the elemental concentration of $\mathrm{N}(\%)$ in different ecosystem compartiments for studied sites at the União

Linear regression between nitrogen $\left(\delta^{15} \mathrm{~N}\right)$ and carbon $\left(\delta^{13} \mathrm{C}\right)$ isotopic composition $(\mathrm{A}, \mathrm{C}$ and E), and between $\delta^{13} \mathrm{C}$ and the elemental concentration of $\mathrm{N}(\%)(\mathrm{B}, \mathrm{D}$, and $\mathrm{F}$ ) for leaves (closed circle), litter fractions (squares: white - rest fraction; dark grey - fruits + flowers fraction; light grey - wood fraction; black - leaf fraction) and soil (closed triangle) in the secondary forest (A and B); site managed 12 months ago (M12) (C and D); and site managed 3 months ago (M3) (E and F) in União Biological Reserve (Rebio União), Brazil. December, 2013. 


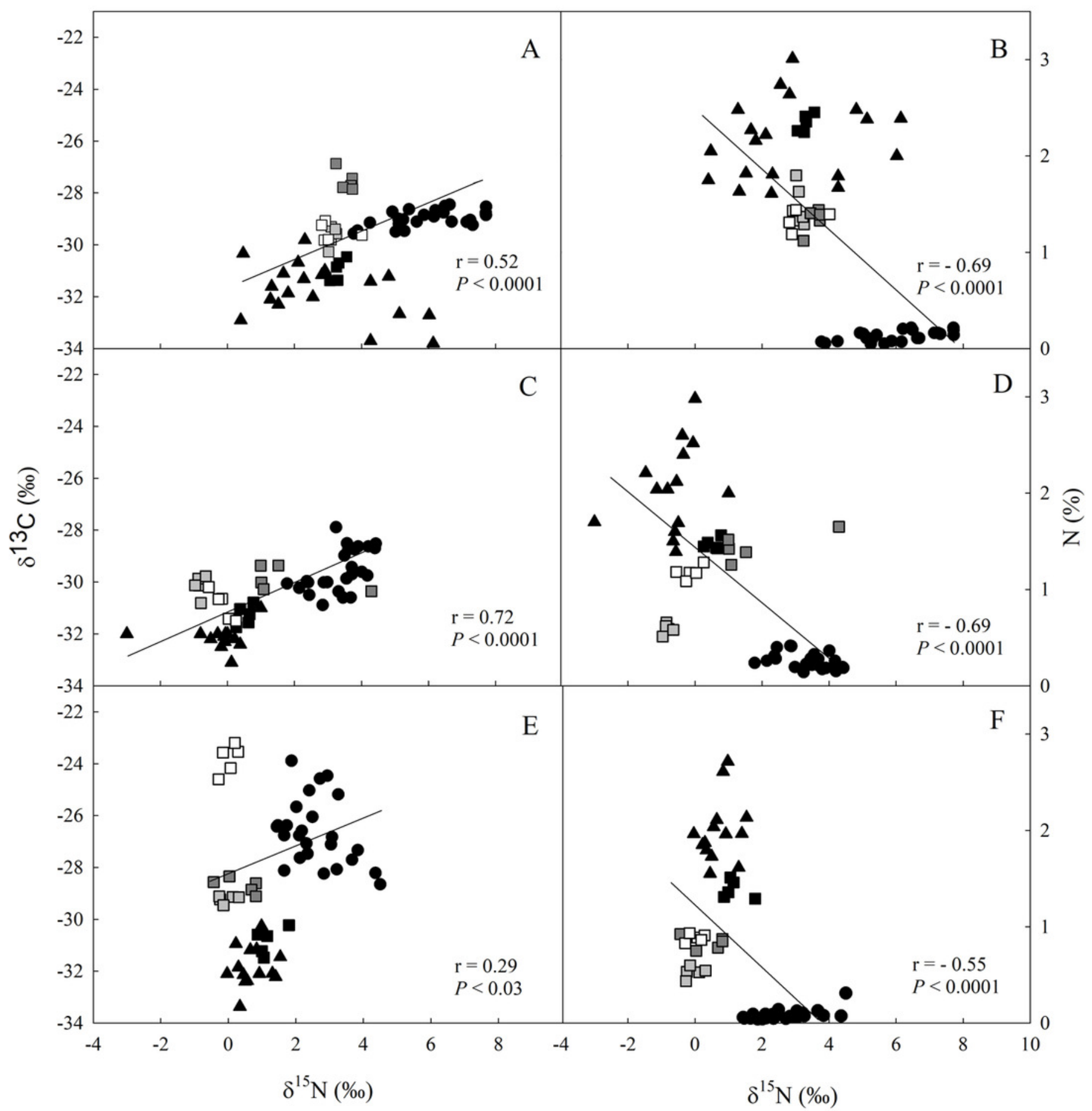


Figure 3

Linear regression between nitrogen isotopic composition $\left(\delta^{15} \mathrm{~N}\right)$ and the in-soil $\mathrm{C} / \mathrm{N}$ ratio in the studied sites at the União Biological Reserve (Rebio União), Brazil.

Linear regression between nitrogen isotopic composition $\left(\delta^{15} \mathrm{~N}\right)$ and the in-soil $\mathrm{C} / \mathrm{N}$ ratio in the secondary forest (black circles), the site managed 12 months ago (M12, white square), and the site managed 3 months ago (M3, grey triangle) at the União Biological Reserve (Rebio União), Brazil. December, 2013.

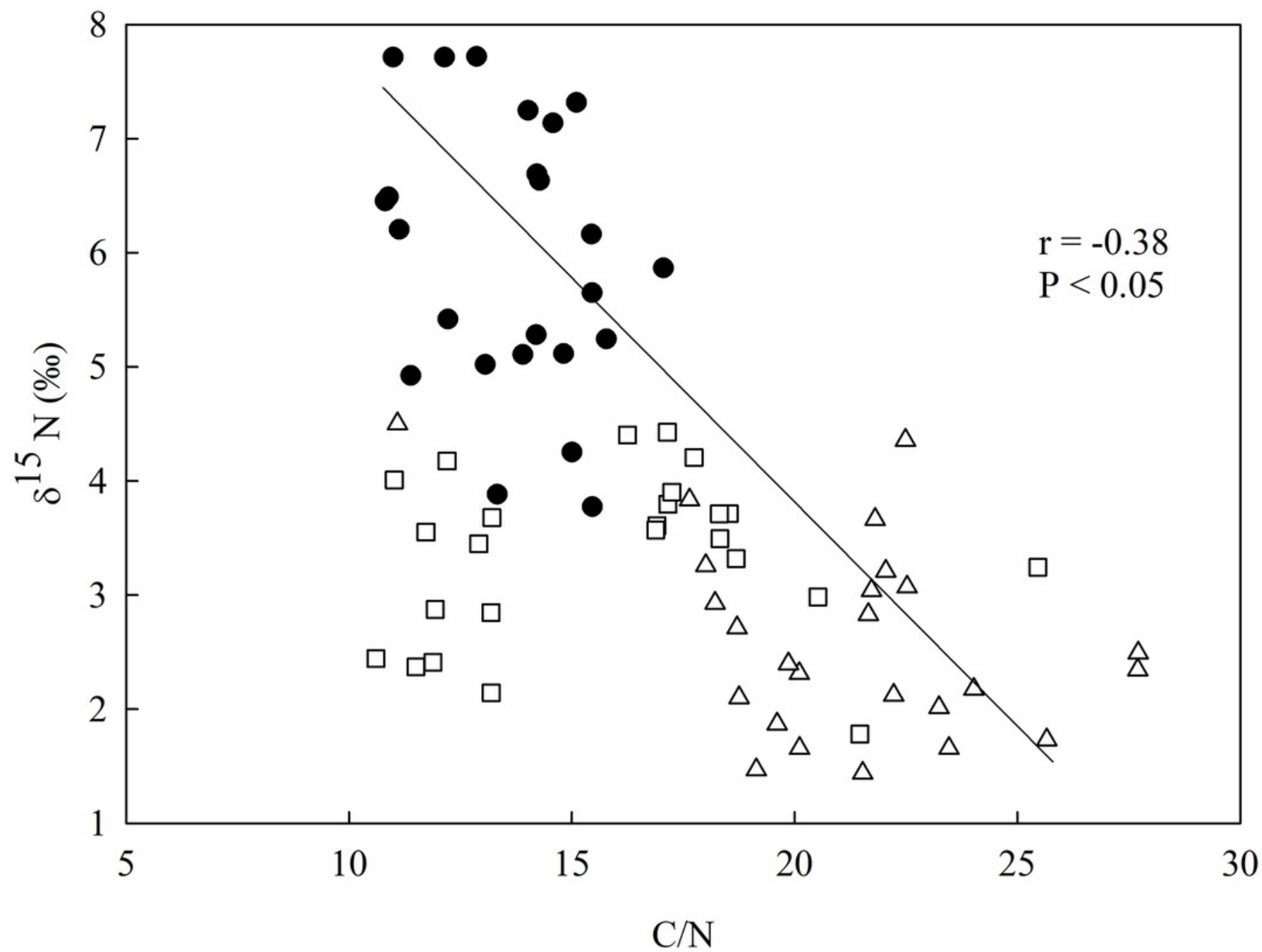




\section{Figure 4}

Mean and standard error (SE) of sand, silt, and clay percentage for the studied sites at the União Biological Reserve.

Mean and standard error (SE) of sand percentage ( $2 \mathrm{~mm}-63 \mu \mathrm{m})$ in white; silt ( $63 \mu \mathrm{m}-4$ $\mu \mathrm{m})$ in light grey; and clay $(<4 \mu \mathrm{m})$ in black in the superficial soil layer in secondary forest; site managed 12 months ago (M12); and site managed 3 months ago (M3) in União Biological Reserve (Rebio União), Brazil. December, 2013. Uppercase letters compare between sites, and lowercase letters compare between fractions.

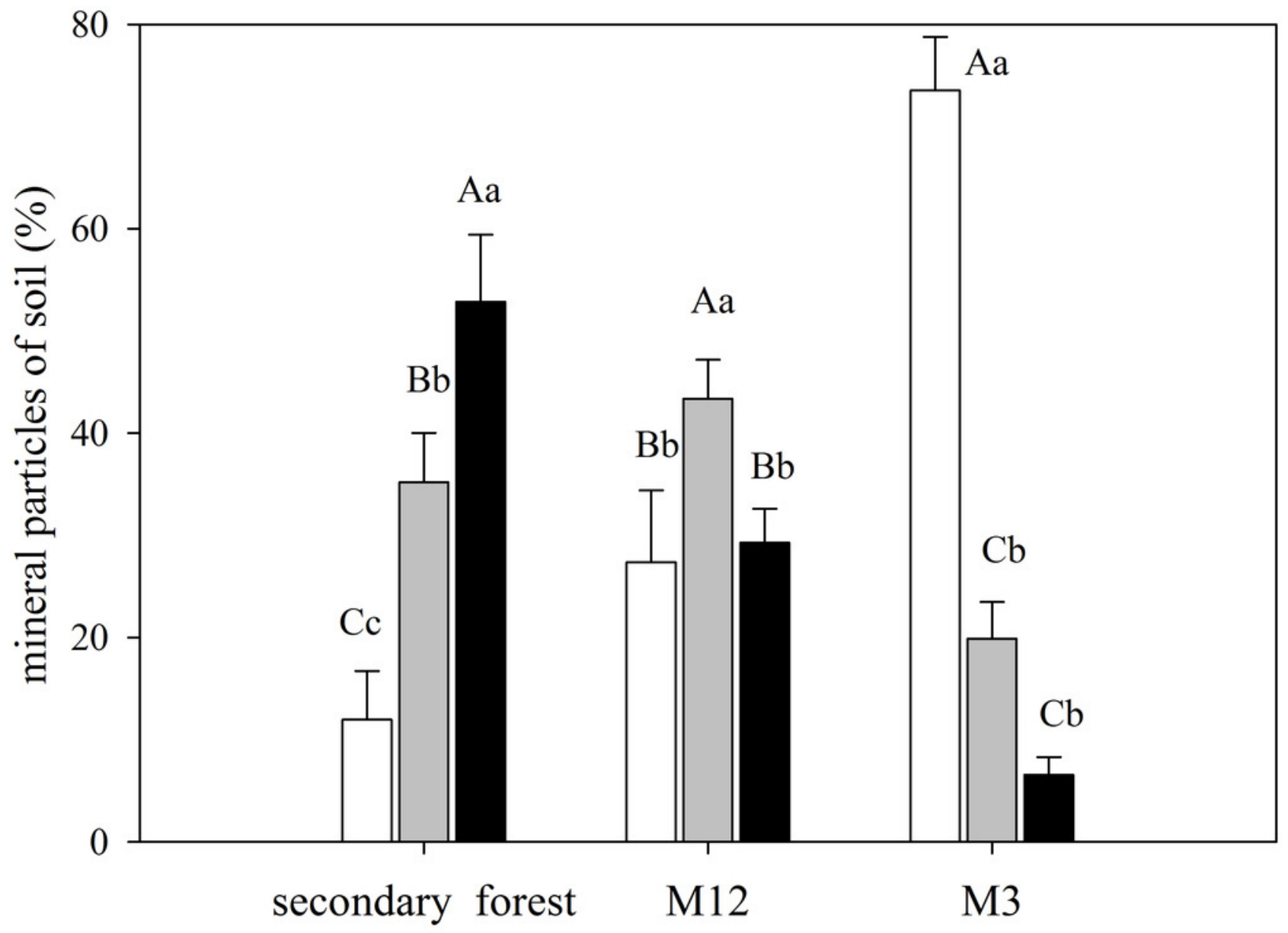




\section{Figure 5}

Mean and SE (standard error) of carbon $\left(\delta^{13} \mathrm{C}\right)$ and nitrogen $\left(\delta^{15} \mathrm{~N}\right)$ isotopic composition in different ecosystem compartments at the União Biological Reserve.

Mean and SE (standard error) of carbon $\left(\delta^{13} \mathrm{C}\right)$ and nitrogen $\left(\delta^{15} \mathrm{~N}\right)$ isotopic composition in leaves, litter fractions (leaves, residue, flower + fruits, and wood) and soil from secondary forest (black); site managed 12 months ago (M12) (light grey); and site managed 3 months ago (M3) (dark grey) in União Biological Reserve (Rebio União), Brazil. December, 2013. Uppercase letters compare between sites, and lowercase letters compare between compartments. 


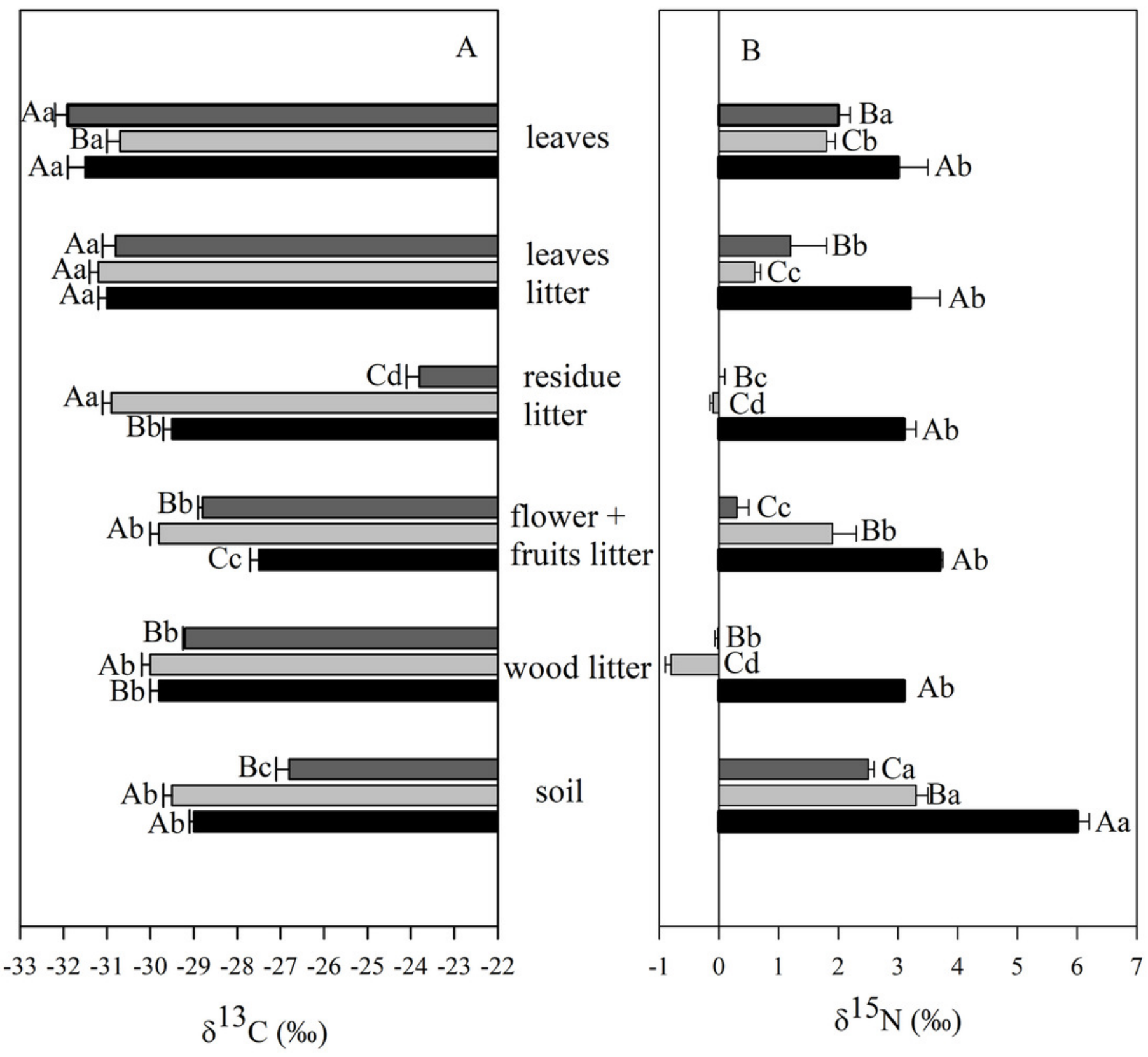




\section{Table $\mathbf{1}$ (on next page)}

Characterization of the study sites.

Characterization of the study sites: secondary forest, managed eucalyptus site clear-cut 12 months ago (M12) and 3 months ago (M3) at the União Biological Reserve (Rebio União), Brazil. December 2013. - not applicable. 


\section{Table 1}

2 Characterization of the study sites: secondary forest, managed eucalyptus site clear-cut 12 months ago 3 (M12) and 3 months ago (3M) União Biological Reserve (ReBioUnião), Brazil. December 2013. - not 4 applicable.

\begin{tabular}{|c|c|c|c|}
\hline & secondary forest & M12 & M3 \\
\hline Understory of native species & Dense vegetation & $\begin{array}{l}\text { Well-developed } \\
\text { vegetation }\end{array}$ & Sparce vegetation \\
\hline Mean irradiance $\left(\mu \mathrm{mol} \mathrm{m} \mathrm{m}^{-2} \mathrm{~s}^{-1}\right)^{\mathrm{a}}$ & 9 & 1.480 & 1.100 \\
\hline Total site (ha) & - & 5,02 & 9,59 \\
\hline Secundary forest distance $(\mathrm{km})$ & - & 1.3 & 0.35 \\
\hline Eucalyptus trees spaced (m) & - & $1,5 \times 3^{b}$ & $1,5 \times 3^{b}$ \\
\hline Eucalyptus removal management & No management & Yes & Yes \\
\hline Management time (months) & - & 12 & 3 \\
\hline Presence of grasses & No & No & Yes \\
\hline
\end{tabular}

5 a values obtained at 1:30m in 30 points between 11:00 and 13:00 h on fifteen sunny day using a quantum 6 sensor (Li-190 coupled to Li-250 A, Li-Cor, USA); ${ }^{\text {b }}$ (MMA-ICMBio, 2008). 


\section{Table 2 (on next page)}

Mean and standard error (SE) of the total concentration for $\mathrm{C}, \mathrm{N}$, and the $\mathrm{C} / \mathrm{N}$ ratio in leaves, litter fractions and soil in the studied sites at the União Biological Reserve.

Mean and standard error (SE) of the total concentration for $\mathrm{C}, \mathrm{N}$, and the $\mathrm{C} / \mathrm{N}$ ratio in leaves, litter fractions (leaves, residue, flower + fruits, and wood) and soil in the secondary forest, sites managed 12 months ago (M12), and sites managed 3 months ago (M3) at the União Biological Reserve (Rebio União), Brazil. December 2013. Uppercase letters compare the sites and the lowercase letters compare the compartments. 


\section{Table 2}

2Mean and $\mathrm{SE}$ of the total concentration for $\mathrm{C}, \mathrm{N}$, and the $\mathrm{C} / \mathrm{N}$ ratio in leaves, litter fractions (leaves, 3residue, flower + fruits and wood) and soil in secondary forest, sites managed 12 months ago (M12), and 4sites managed 3 months ago (M3) in União Biological Reserve (ReBioUnião), Brazil. December 2013. 5Uppercase letters compare the sites and the lowercase letters compare the compartments.

6

\begin{tabular}{|c|c|c|c|c|}
\hline Site & Fraction & $\mathrm{C}(\%)$ & $\mathbf{N}(\%)$ & $\mathbf{C} / \mathbf{N}$ \\
\hline \multirow{4}{*}{$\begin{array}{l}\text { secondary } \\
\text { forest }\end{array}$} & leave & $42.4 \pm 0.4 \mathrm{Bb}$ & $2.1 \pm 0.1 \mathrm{Aa}$ & $21.1 \pm 0.5 \mathrm{Bb}$ \\
\hline & leaves litter & $46.9 \pm 0.7 \mathrm{Ba}$ & $2.3 \pm 0.1 \mathrm{Aa}$ & $23.4 \pm 0.5 \mathrm{Cb}$ \\
\hline & residue litter & $50.1 \pm 0.6 \mathrm{Aa}$ & $1.4 \pm 0.1 \mathrm{Ab}$ & $43.4 \pm 1.3 \mathrm{Ba}$ \\
\hline & flower + fruit litter & $47.7 \pm 0.1 \mathrm{Aa}$ & $1.3 \pm 0.1 \mathrm{Ab}$ & $42.0 \pm 1.9 \mathrm{Ba}$ \\
\hline \multirow{9}{*}{ M12 } & wood litter & $46.5 \pm 1.9 \mathrm{Aa}$ & $1.5 \pm 0.1 \mathrm{Ab}$ & $36.9 \pm 1.4 \mathrm{Ba}$ \\
\hline & soil & $1.5 \pm 0.1 \mathrm{Bc}$ & $0.1 \pm 0.1 \mathrm{Bc}$ & $16.5 \pm 2.8 \mathrm{Ac}$ \\
\hline & leave & $44.8 \pm 0.7 \mathrm{Ab}$ & $2.6 \pm 0.2 \mathrm{Aa}$ & $44.8 \pm 2.4 \mathrm{Ab}$ \\
\hline & leave litter & $48.6 \pm 0.4 \mathrm{Ba}$ & $1.5 \pm 0.1 \mathrm{Ba}$ & $38.6 \pm 0.5 \mathrm{Bc}$ \\
\hline & residue litter & $48.4 \pm 0.6 \mathrm{Aa}$ & $1.2 \pm 0.1 \mathrm{Bb}$ & $48.0 \pm 0.8 \mathrm{Bb}$ \\
\hline & flower + fruit litter & $49.8 \pm 0.3 \mathrm{Aa}$ & $1.5 \pm 0.1 \mathrm{Aa}$ & $40.5 \pm 1.6 \mathrm{Bb}$ \\
\hline & wood litter & $48.4 \pm 0.8 \mathrm{Aa}$ & $0.6 \pm 0.1 \mathrm{Bc}$ & $96.3 \pm 4.5 \mathrm{Aa}$ \\
\hline & soil & $3.3 \pm 0.1 \mathrm{Ac}$ & $0.3 \pm 0.1 \mathrm{Ad}$ & $15.8 \pm 0.8 \mathrm{Ad}$ \\
\hline & leave & $45.2 \pm 0.5 \mathrm{Aa}$ & $2.0 \pm 0.2 \mathrm{Ba}$ & $23.4 \pm 0.9 \mathrm{Bc}$ \\
\hline \multirow{5}{*}{ M3 } & leaves litter & $51.4 \pm 1.1 \mathrm{Aa}$ & $1.4 \pm 0.1 \mathrm{Ba}$ & $43.3 \pm 0.9 \mathrm{Ab}$ \\
\hline & residue litter & $45.1 \pm 0.4 \mathrm{Ba}$ & $0.9 \pm 0.1 \mathrm{Cb}$ & $59.6 \pm 1.4 \mathrm{Aa}$ \\
\hline & flower + fruit litter & $46.3 \pm 0.6 \mathrm{Aa}$ & $0.8 \pm 0.1 \mathrm{Bb}$ & $65.1 \pm 2.7 \mathrm{Aa}$ \\
\hline & wood litter & $47.5 \pm 0.6 \mathrm{Aa}$ & $0.5 \pm 0.1 \mathrm{Bb}$ & $106.2 \pm 5.9 \mathrm{Aa}$ \\
\hline & soil & $1.5 \pm 0.1 \mathrm{Bb}$ & $0.2 \pm 0.1 \mathrm{Bc}$ & $21.2 \pm 0.7 \mathrm{Ac}$ \\
\hline
\end{tabular}




\section{Table 3 (on next page)}

Organic matter decomposition from the difference between $\delta^{13} \mathrm{C}$ and $\delta^{15} \mathrm{~N}$ values of the soil and the different litter fractions for the secondary forests.

Organic matter decomposition from the difference between $\delta^{13} \mathrm{C}$ and $\delta^{15} \mathrm{~N}$ values of the soil and the different litter fractions (leaves, residue, flower + fruits, and wood) at the União Biological Reserve (Rebio União), Brazil in secondary forest, site managed12 months ago (M12) and site managed 3 months ago (M3). 


\section{Table 3}

2 Organic matter decomposition from the difference between $\delta^{13} \mathrm{C}$ and $\delta^{15} \mathrm{~N}$ values

3 of the soil and the different litter fractions (leaves, residue, flower + fruits and

4 wood) in União Biological Reserve (ReBioUnião), Brazil in secondary forest, site

5 managed12 months ago (M12) and site managed 3 months ago (M3).

6

\begin{tabular}{clcc}
\hline \multicolumn{1}{c}{ Site } & \multicolumn{1}{c}{ Decomposition } & $\boldsymbol{\delta}^{\mathbf{1 3}} \mathbf{C}(\% \mathbf{0})$ & $\boldsymbol{\delta}^{\mathbf{1 5}} \mathbf{N}(\% \mathbf{0})$ \\
\hline \multirow{2}{*}{ secondary forest } & leave litter & 2.0 & -2.7 \\
& residue litter & 0.5 & -2.9 \\
& flower + fruit litter & -1.5 & -2.4 \\
& wood litter & 0.7 & -2.9 \\
& & & \\
M12 leave litter & residue litter & 1.7 & -2.8 \\
& flower + fruit litter & 1.3 & -3.3 \\
& wood litter & 0.3 & -1.6 \\
& & 0.6 & -2.5 \\
& leave litter & 4.2 & -1.4 \\
M3 & residue litter & -2.8 & -2.6 \\
& flower + fruit litter & 2.0 & -2.2 \\
& wood litter & 2.6 & -2.6 \\
\hline
\end{tabular}

7

8 